\title{
MFH Strap Design
}

\section{D-Zero Engineering Note \#3740.222-EN-197}

$$
\begin{gathered}
11-18-88 \\
\text { Revised } \\
4-4-89
\end{gathered}
$$

Approved by Keith. Primdahl

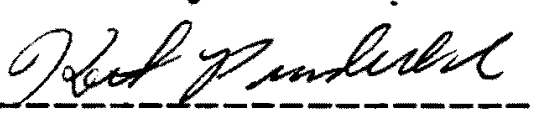




\section{Background}

In the end calorimeter of the D-zero experiment, uranium and stainless steel plates are assembled into modules which are to be installed into the cryostat as individual units. A single inner module will be surrounded by sixteen middle modules, which are surrounded by sixteen outer modules.

The earlier design of the support structure of each middle hadronic module of the end calorimeter consisted of a stainless steel skin "wrapped" around the plates. Recently, it became clear that a system of straps, instead of skin, offered several advantages.

Specifically, high voltage and read-out cables could be attached after assembly, most signal wire ganging connectors could be accessible for maintenance, and there would be less resistance to convective flow of argon vapor during cool-down and warm-up. Unlike the stainless steel plates of the coarse section, uranium plates cannot be welded to the straps.

A series of four configurations were designed, constructed, and tested. This report describes testing of the fourth design, which has been selected for construction. Drawings are included in appendix 1 .

\section{Module Orientation}

The modules of the end calorimeter are trapezoidal shapes arranged in a ring, centered around the beam path. The test modeled the MFH in the 6:00 position of the ring. For several reasons this module is expected to be the most severely loaded:

-The two outer radius angles are at the bottom of the module and will be required to support the weight of the uranium plates in addition to the moment induced by the connection to the coarse section.

- The outer radius angles are smaller than the inner radius angles. Specifically, the flange on the side between modules is 1.625 "for the outer radius angle, and 3.000" for the inner radius angle. 
- The 6:00 orientation is the case where the module is closest to being simply supported. Since the modules are connected at the outer radius, other orientations are supported in a manner that could be described as between simply supported and fixed/guided.

-In all orientations except 6:00, the "wedge" shape may allow for some sharing of loads with other module support members. Also, the flanges facing the $\mathrm{IH}$ and $\mathrm{OH}$ are 0.188 " thick, while the side flanges are $0.075^{\prime \prime}$ thick $\left(0.060^{\prime \prime}\right.$ for test).

\section{Comparison of Test Conditions and Installed Conditions}

The loading of the test module, cantilevered from the test stand, with lead bricks, and tip force from below, nearly duplicate the loads expected when attached to a coarse section and installed in the end calorimeter (see appendix 2 for calculations):

Support Loads

Weight of fine section (lb) Support Force, max. shear Moment (max) at back of center plate (in lb)

Shear at back of center plate
As Installed

5450

(lb) As Tested

$4820 \quad(88 \%)$ $6000(119 \%)$

$111,700 \quad(160 \%)$ $1180(246 \%)$

The above results for the installed module assume a "beam" of uniform properties. The moment may be slightly different since the coarse section is much more stiff than the fine section. The test stand was assumed to be infinitely stiff for the tested case. Strap thickness for the tested case was 0.060 ", while actual construction will utilize $0.075^{\prime \prime}$ thick material. Hence, actual modules can be expected to be $20 \%$ stronger than the tested MFH. All data presented in this report is for the $0.060 "$ straps, no adjustment has been made for increased strength of $0.075^{\prime \prime}$ straps.

\section{Pre-Load (Modeling the Warm-up Case)}

When assembled, the stack of uranium plates and pins will be compressed while straps are welded to the stainless steel end plates. When released from the welding fixture, the plates and pins will be in compression, the straps in tension. The cool-down case, where the straps are at $250 \mathrm{~K}$ while the plates and pins are at $293 \mathrm{~K}$ results in 
the highest pre-load stresses on the plates, pins and straps (a preweld $15,000,3$ compression has been assumed for these estimates):

$\begin{array}{lr}\text { Maximum Pin \& Plate Stress } & -21,200 \text { psi } \\ \text { Maximum Strap Stress } & 4,800 \text { psi }\end{array}$

During warm-up it is possible for the stainless steel straps to be warmer than the bulk of the uranium plates and stainless steel pins. This difference in temperature, and corresponding difference in thermal expansion, will reduce the compressive pre-load on the stack. For the case where the plates and pins are at $250 \mathrm{~K}$ and the straps are at 293K, the stack might expand 0.023" . (appendix 3).

In order to simulate the warm-up, or loose, condition during testing, the relation between stack height and pre-load was measured. The stack was compressed, released, then compressed again. In previous stack compression tests, the first set of data indicates a "shake-down" occurs, possibly due to movement of pins on plates. Second and subsequent compressions have always shown good repeatability. In appendix 4, the change in stack length is plotted as a function of compressive load. It can be seen that the data tends toward a linear relation as the compressive force is increased. For this upper region the compressive force is plotted as a function of change in stack length (axes switched w/respect to the first plot). Here, the spring constant of the stack is the slope of a straight line through the data. This result can be compared to the theoretical value based on the plate and pin thickness, and their Young's modulus:

Theoretical spring constant, $k$ (lb/in) 937,500

Measured spring constant, k (lb/in) 398,000

The difference is due to the waviness and/or thickness variation of the uranium plates.

It is presently anticipated that during production, the stacks will be compressed to $10,000 \mathrm{lb}$ and welded. For the test module, its stack height at $10,000 \mathrm{lb}$ was noted, then it was allowed to expand by .022". While subject to this expanded pre-load, the corner straps were welded and allowed to cool, then the struts were welded. The final pre-load on the stack was estimated to be $7500 \mathrm{lb}$. A significant portion of this pre-load can be attributed to weld shrinkage in the corner angles. 
Pre-load carried by the struts is small, compared to the total pre-load. In fact, we have learned that the more massive corner angles must be welded and allowed to shrink before the struts are welded; otherwise, there will be no pre-load in the struts. Also, the bending component of this pre-load is in the opposite direction of the loaded module case. For this test, the strut pre-load stress was as follows:

$\begin{array}{lc}\text { Primary Pre-Load Stresses } & \text { Larger of the 2 Sides } \\ \text { Membrane stress (psi) } & 720 \\ \text { Bending at the gage (psi) } & 290 \\ \text { Bending extrapolated to } & 520 \\ \text { the extreme fiber (psi) } & \\ \begin{array}{c}\text { Membrane plus bending at } \\ \text { the extreme fiber (psi) }\end{array} & 1240\end{array}$

\section{Measured Stresses}

The critical stress areas are the strut near its weld to the front plate, and the joint of the struts with the center of the outer radius angle. The jack force was cycled from zero to $6000 \mathrm{lb}$ twice. At $1875 \mathrm{lb}$ jack force, the module is supported in a neutral position; that is, the tip deflection (from beam theory) is zero. For a jack force less than $1875 \mathrm{lb}$, the module is bending towards the floor due to the weight of the plates and bricks, for a jack force above $1875 \mathrm{lb}$, the module is bending toward the ceiling. The data shows a "kick" where the bending changes direction. The data is nearly linear, with good repeatability. This indicates no yielding or permanent shape change occurred.

By comparing the stress intensity measured near the upper and lower fiber of the strut, the membrane stress can be separated from the bending stress. Considering the second and third loadings 
to $6000 \mathrm{lb}$ (a complete set of plots appears in appendix 4):

Strut. Near Front Plate_Larger of the 2 Sides

$\begin{array}{lr}\text { Membrane stress (psi) } & 11,750 \\ \text { Bending at the gage (psi) } & 930 \\ \begin{array}{l}\text { Bending extrapolated to } \\ \text { the extreme fiber (psi) }\end{array} & 1670 \\ \begin{array}{c}\text { Membrane plus bending at } \\ \text { the extreme fiber (psi) }\end{array} & 13,420\end{array}$

Strut/Outer Radius Joint___Larger of the 2 Sides

Membrane stress (psi)

Bending at the gage (psi)

Bending extrapolated to the extreme fiber (psi)

Membrane plus bending at the extreme fiber (psi)
13,700

3010

6010

19,710

Where the struts connect with the outer radius angle; that is, the other end of the strut, the stresses can be no greater than the case above.

There was no buckling during the testing of this design. An earlier design had buckled near the inner radius' (the tallest flange of the straps) connection to the front plate; however, the resulting tip deflection of that test was still acceptable. Since the actual straps will be $20 \%$ thicker than those tested, there is sufficient safety margin against buckling.

In earlier tests performed under the direction of Kurt Krempetz, it was found that the strength of butt welds in stainless steel was equal to the strength of the material itself. This is as expected, since the filler rod is of the same material. No effort has been made to take advantage of the increased strength of stainless steel due to cold rolling. 


\section{Comparison of Stresses With Code Allowed Limits}

The ASME Pressure Vessel Code gives the following guidelines:

For primary membrane stress

For primary membrane plus primary bending stress $\quad(1.5)\left(S_{m}\right)$

For primary and secondary membrane plus bending stress $\quad(3.0)\left(S_{m}\right)$

Where $S_{m}$ is the Design Stress Intensity. For AISI 304 (UNS S30400) stainless Steel, the ASME tables (Section VIII, Division 2) list $S_{m}=20,000$ psi. This results in limits of:

For primary membrane stress

$20,000 \mathrm{psi}$

For primary membrane plus primary bending stress

30,000 psi

For primary and secondary membrane plus bending stress $\quad 60,000$ psi

So the measured stress is acceptable under the ASME Pressure Vessel Code. However, the MH module is not a pressure vessel; hence, it is wise to consider the guidelines of the AISC code for structural steel. Although the AISC code does not directly address the use of stainless steel, allowable stresses can be calculated from code formulas, using a yield strength, $F_{y}$ of 30,000 psi for 304 stainless steel.

Tension

$$
\begin{aligned}
(0.6)\left(F_{y}\right) & =18,000 \mathrm{psi} \\
(0.66)\left(F_{y}\right) & =19,800 \mathrm{psi} \\
(0.9)\left(F_{y}\right) & =27,000 \mathrm{psi}
\end{aligned}
$$

Bending

Compression

For tension plus bending, the following formula is provided:

$$
\begin{aligned}
& f_{a} /\left(0.60 F_{y}\right)+f_{b x} /\left(0.9 F_{y}\right)<1.0 \\
& f_{a}=\text { axial tension } \\
& f_{b x}=\text { in plane bending force } \\
& F_{y}=\text { yield strength }
\end{aligned}
$$


Using data from the larger of the two sides, with $5000 \mathrm{lb}$ (design load) jack force, for the stress in the strut/outer radius joint extrapolated to the extreme fiber (the worst case):

$$
13700 \mathrm{psi} / 18000 \mathrm{psi}+6010 \mathrm{psi} / 27000 \mathrm{psi}=0.98
$$

which is acceptable.

\section{Deflections (Permanent Shape Change)}

For a cantilevered beam with an evenly distributed weight, and a tip load equal to three-eighths the weight there is no tip deflection. Accordingly, the deflection results have been adjusted to approximate this horizontal starting position. The largest tip deflection, with $6000 \mathrm{lb}$ jack force, was $0.021 \mathrm{in}$. With no jack force, the largest tip deflection was -0.005 in. Hence, the largest deflection possible, regardless of the selected zero point, is $0.026 \mathrm{in}$, which is acceptable. Tip deflections for the two cycles, plotted in appendix 4, were nearly identical.

Even though the module nearly returned to its horizontal position in the tests, there is no reason to belive that this would occur when installed in the cryostat. In fact, since the module will be cycled thermally, with constant support forces (just the opposite of test conditions), It is believed that the module will sag at the center plate approximately the same distance as the above tip deflection during the first warm-up, then remain in this position.

\section{Conclusion}

The fourth MFH strap design described in this report is adequate for the expected loads during cool down and warm up in the end calorimeter. 
Appendix 1

Drawings 
ax. onminion

\begin{tabular}{|l|l}
\hline A & 36.750 पams 28.750 \\
\hline
\end{tabular}

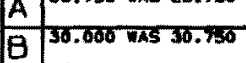
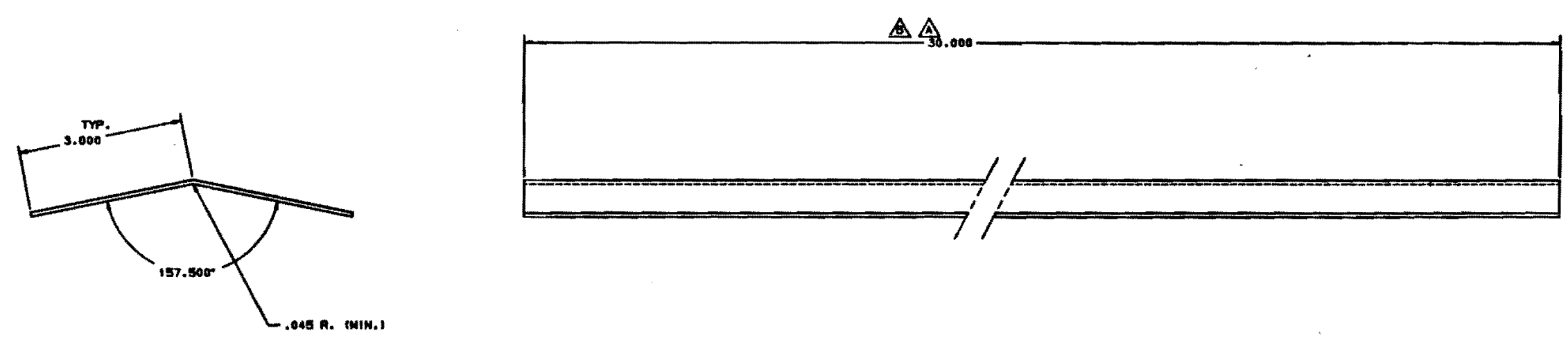

GEN. NOTE:

1. WeEs onEmise

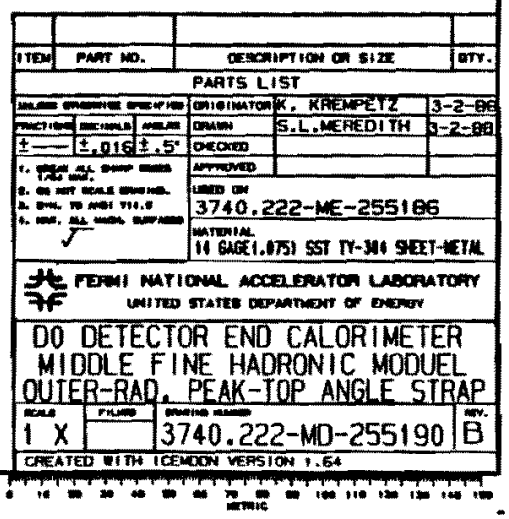


.......
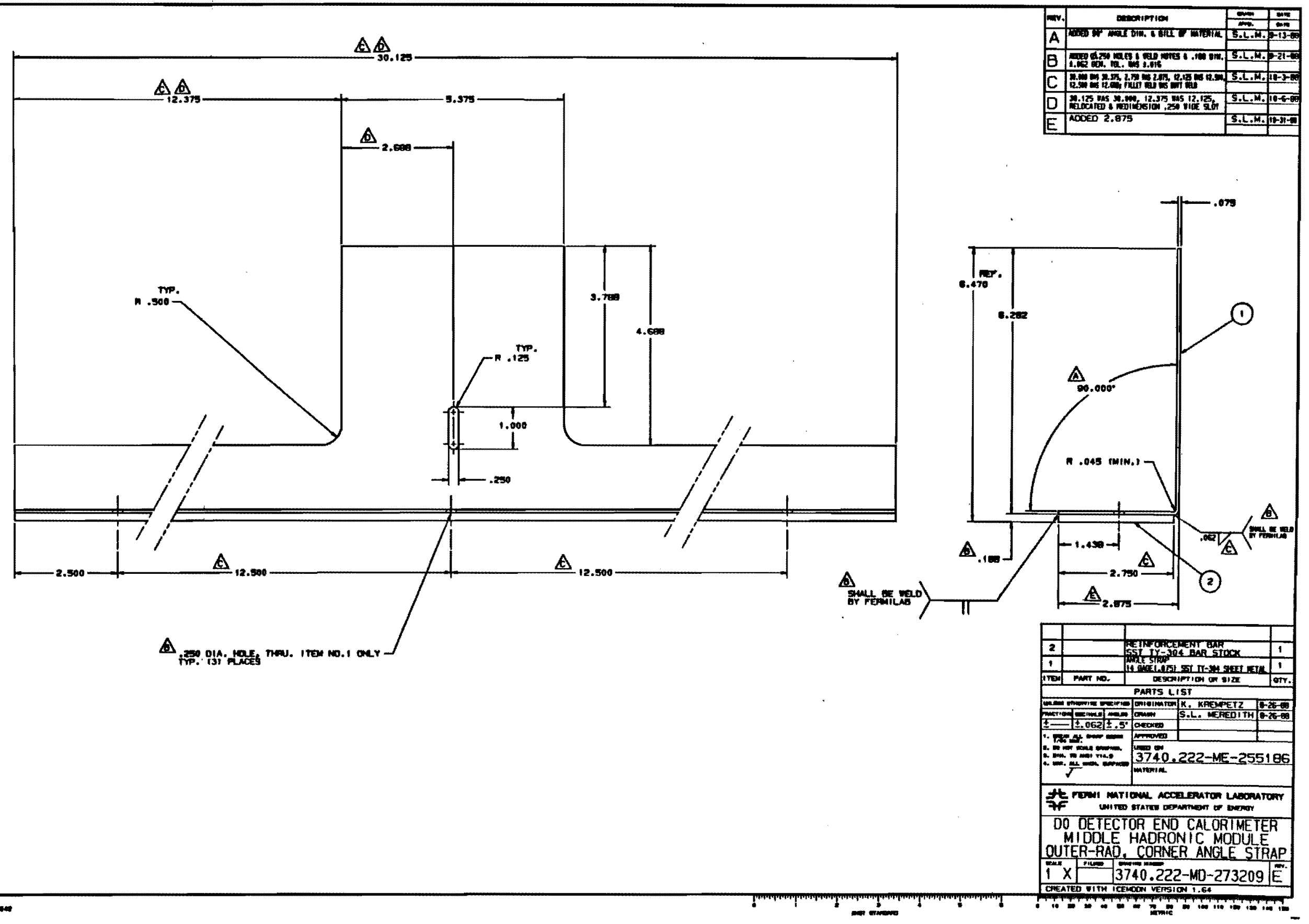


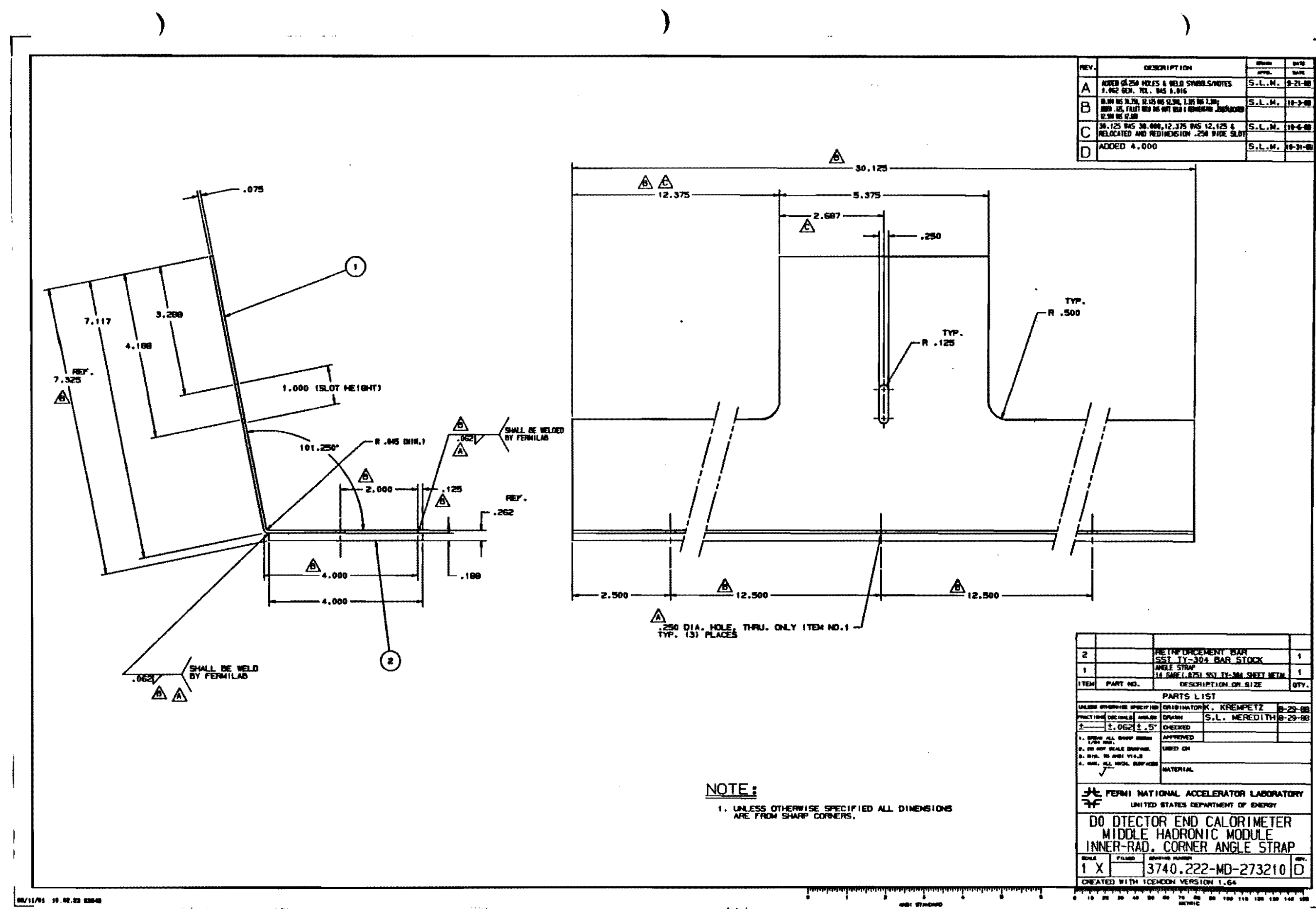




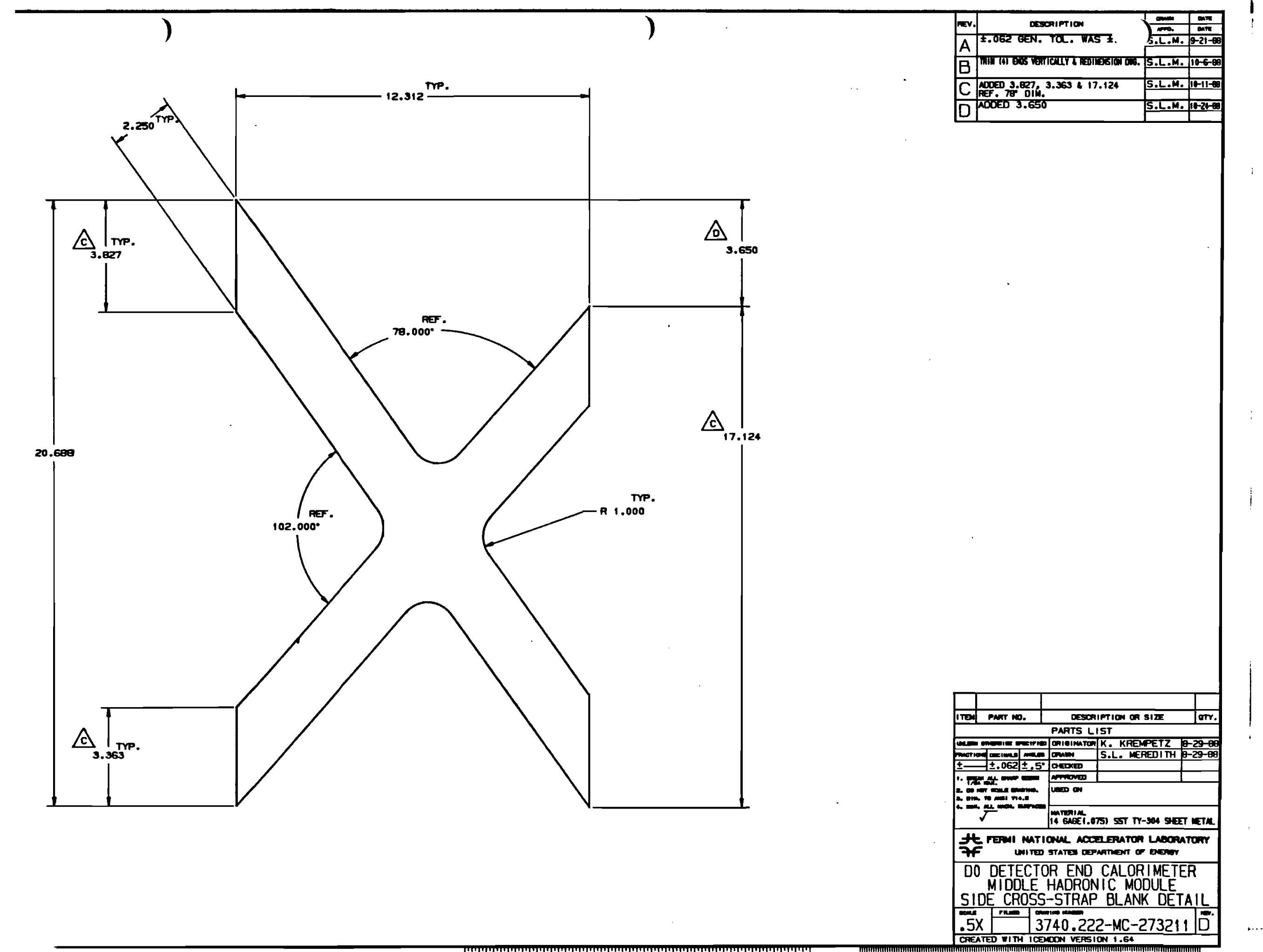




\section{Appendix 2 Comparison of Expected and Tested Loads}




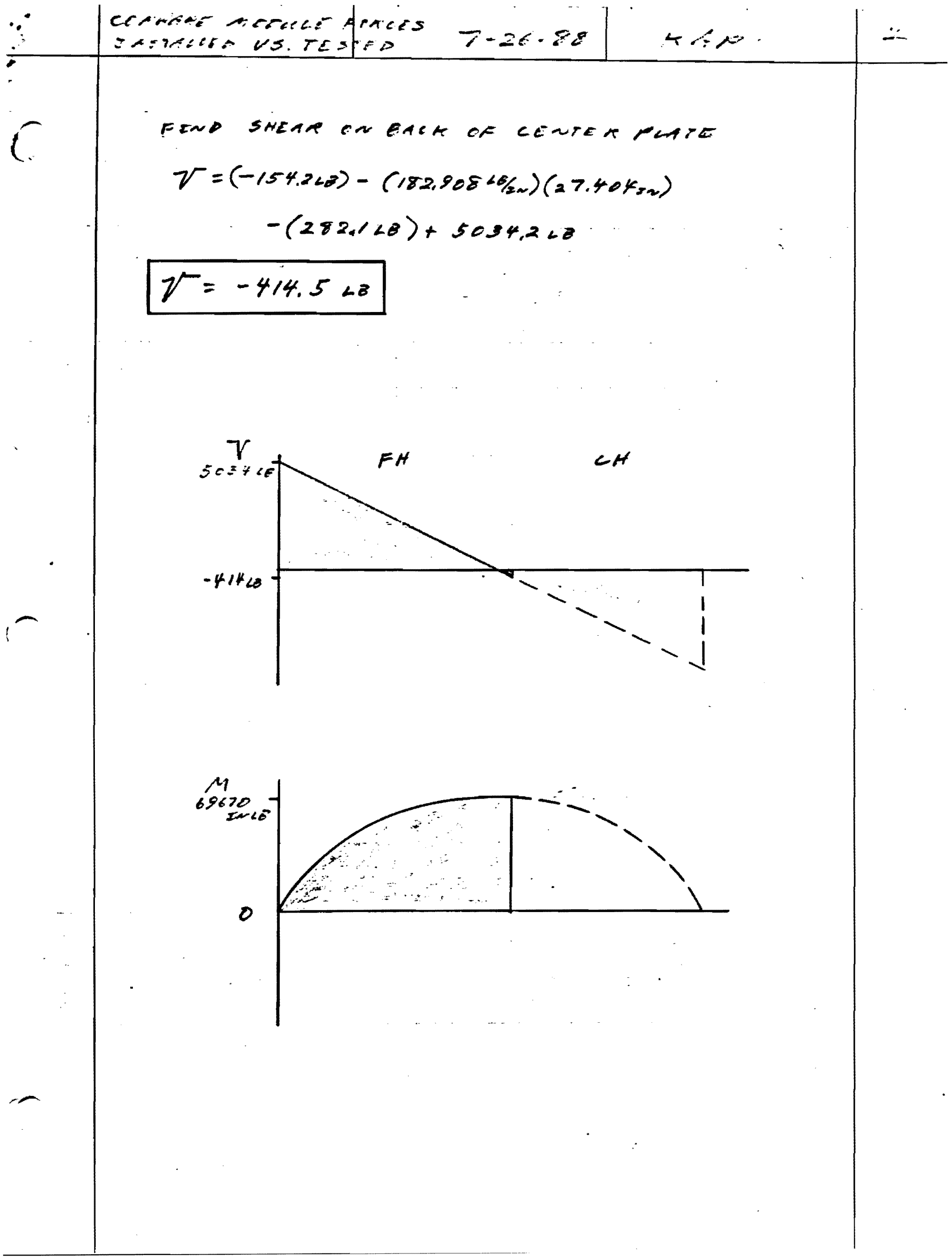




\section{Appendix 3 \\ Spring Constant \& \\ Thermal Expansion Differential Calculations}




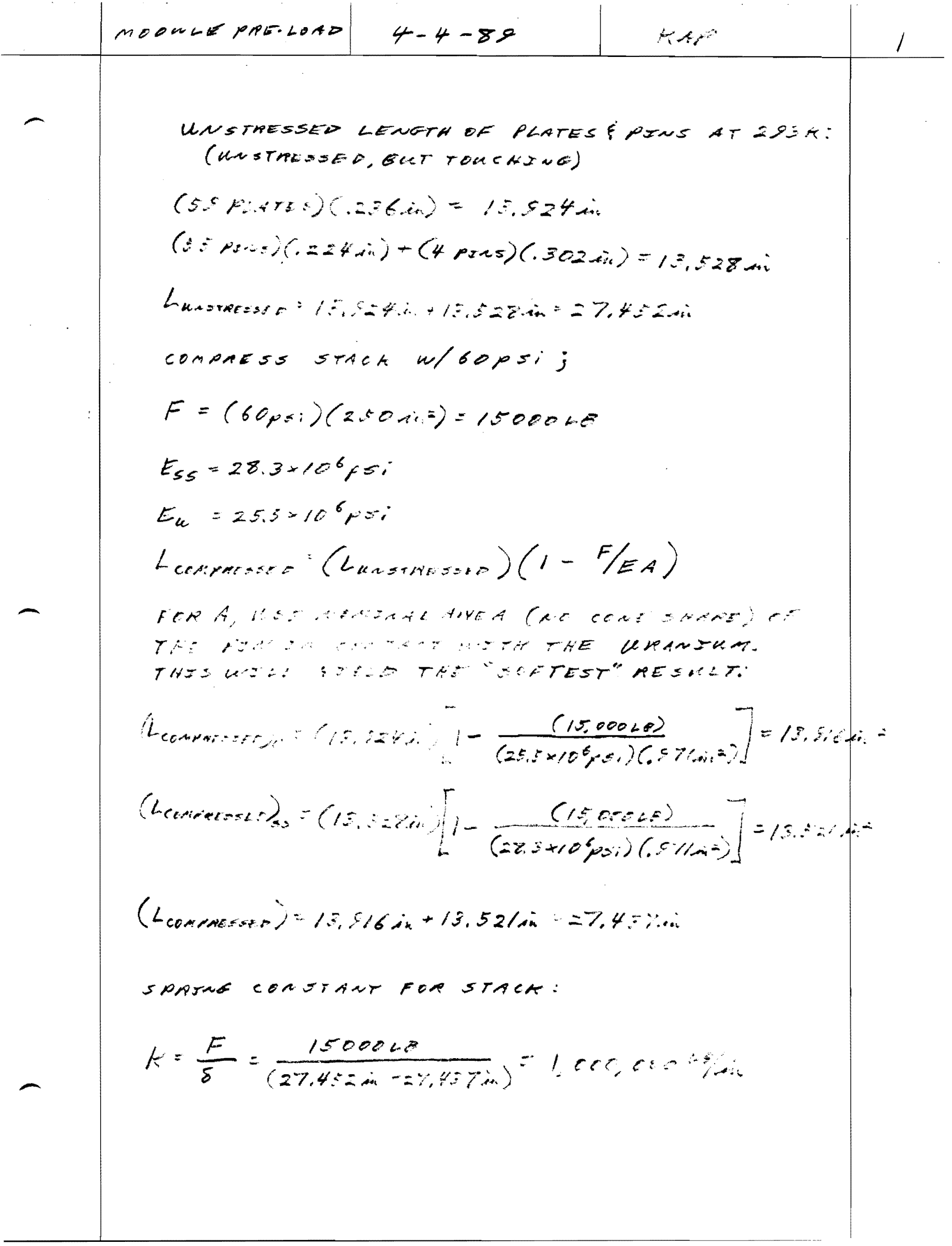




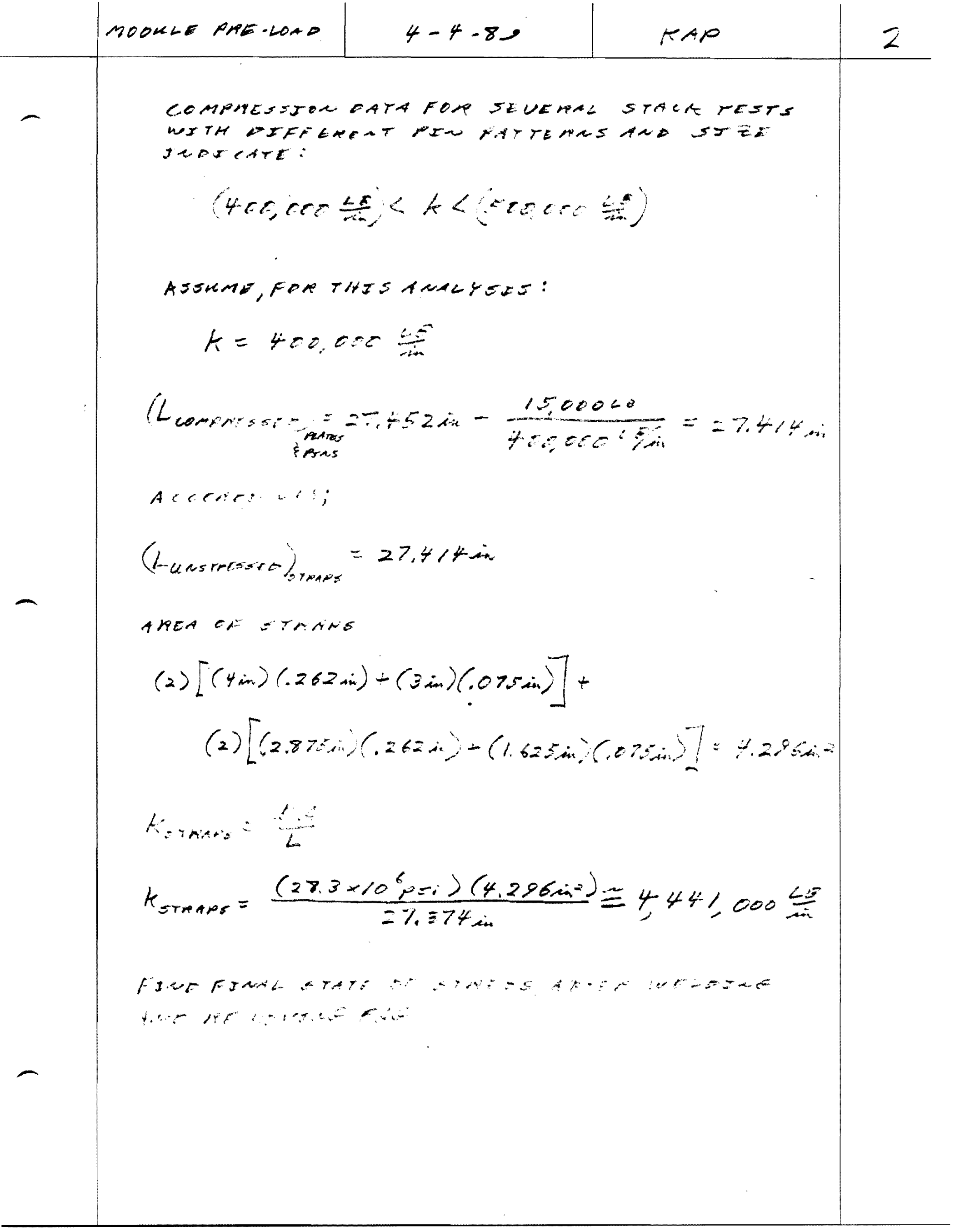




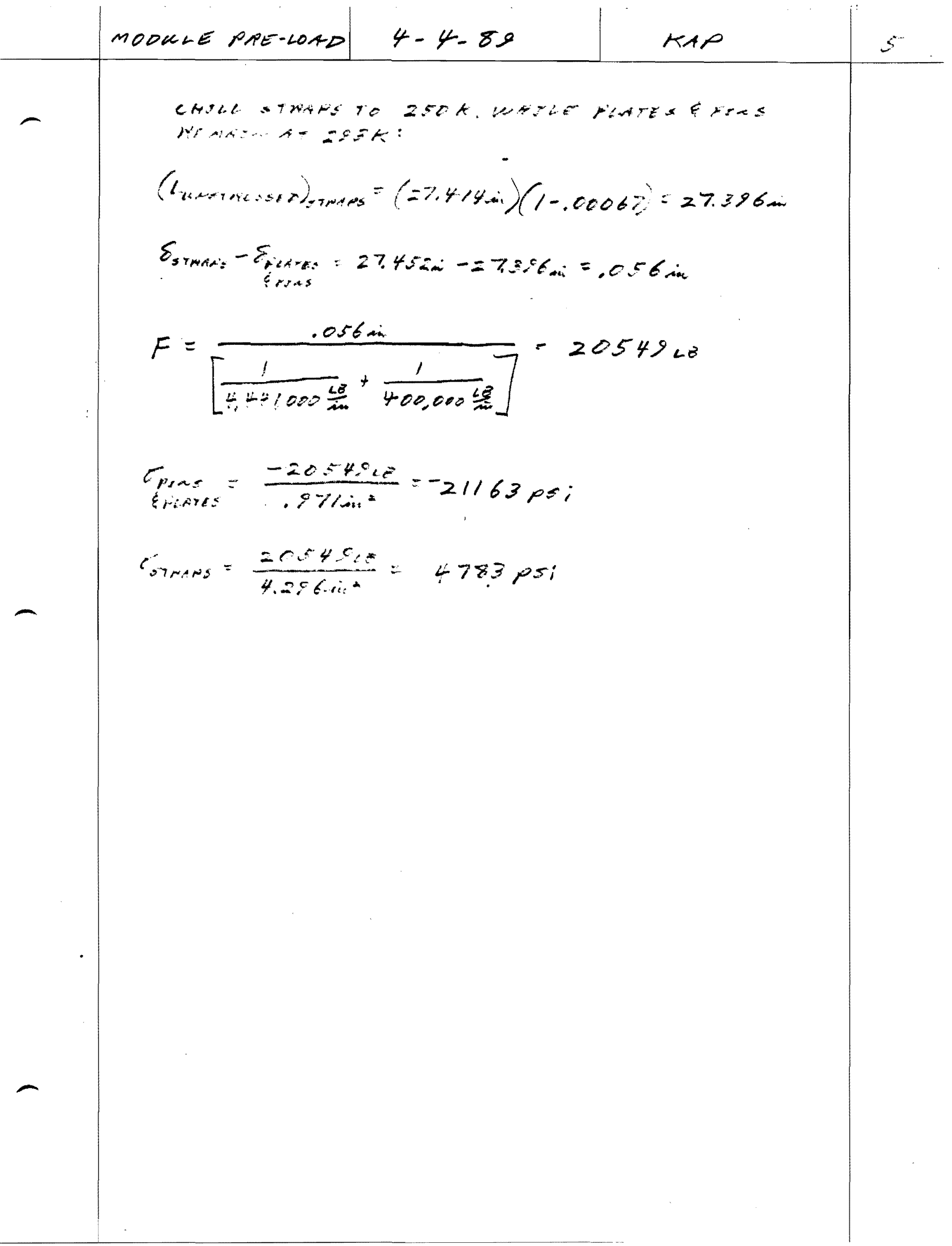




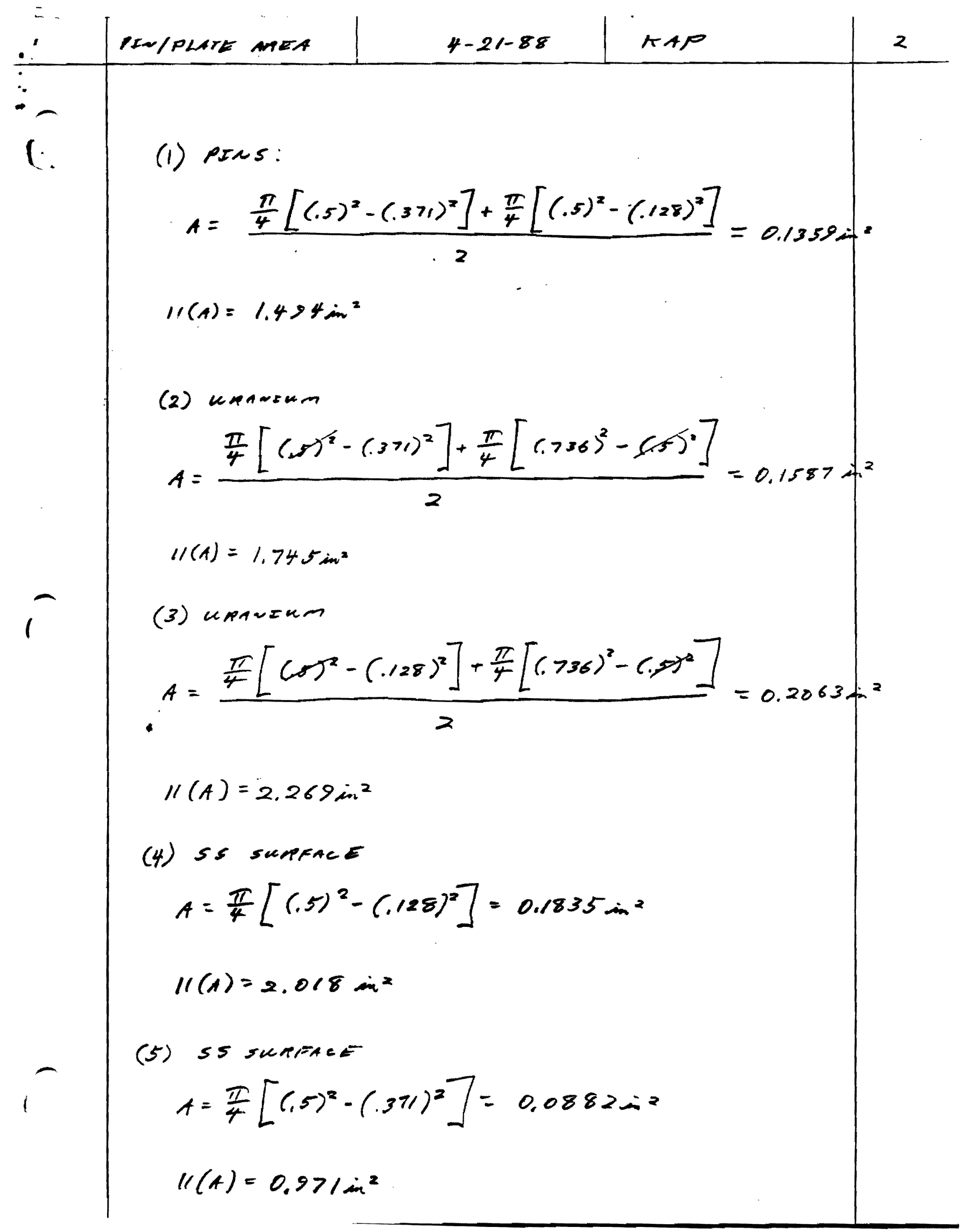


Appendix 4

Plots 
Data from "Fourth MFH Model, 8-23-88"

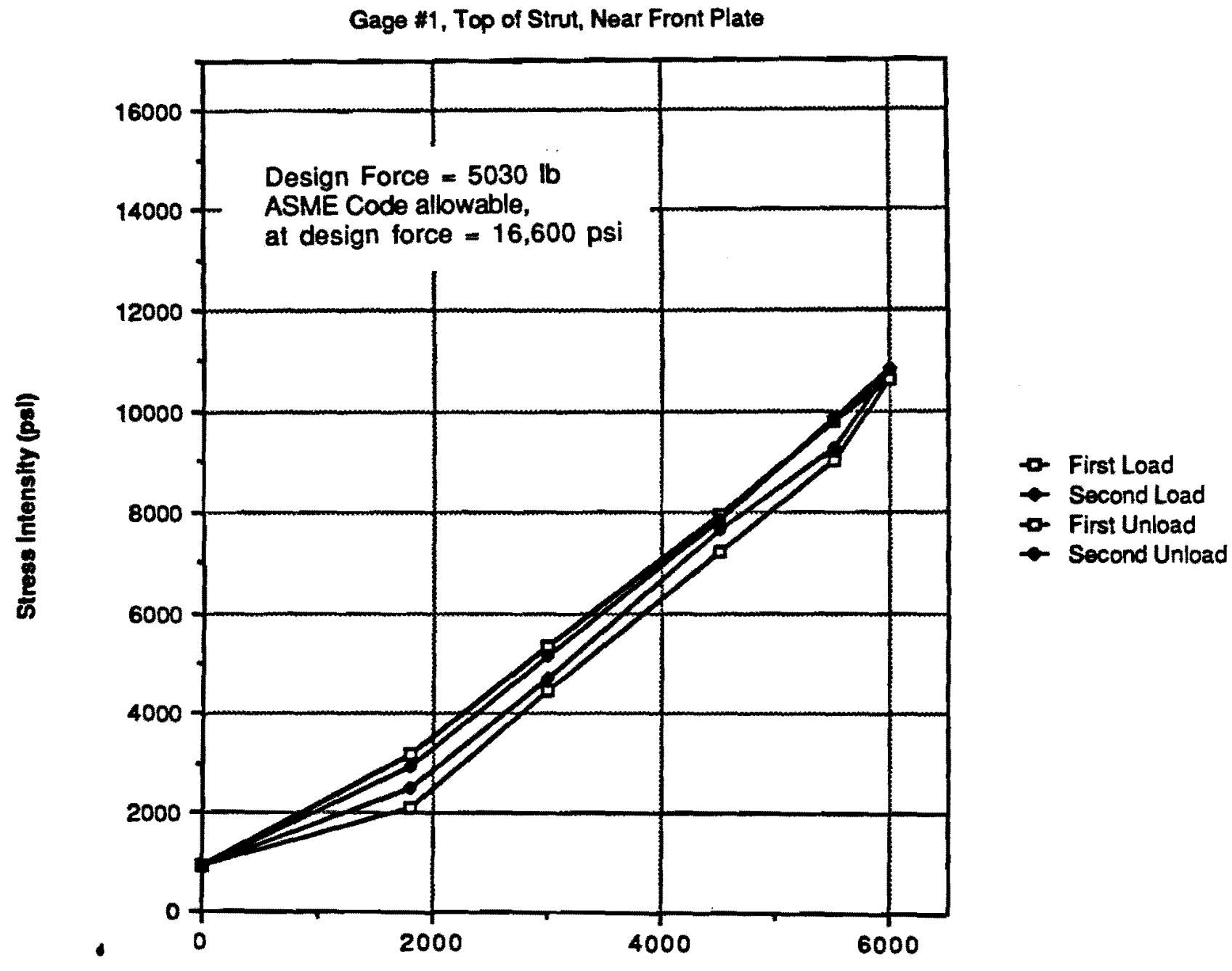

Jack Force (16)

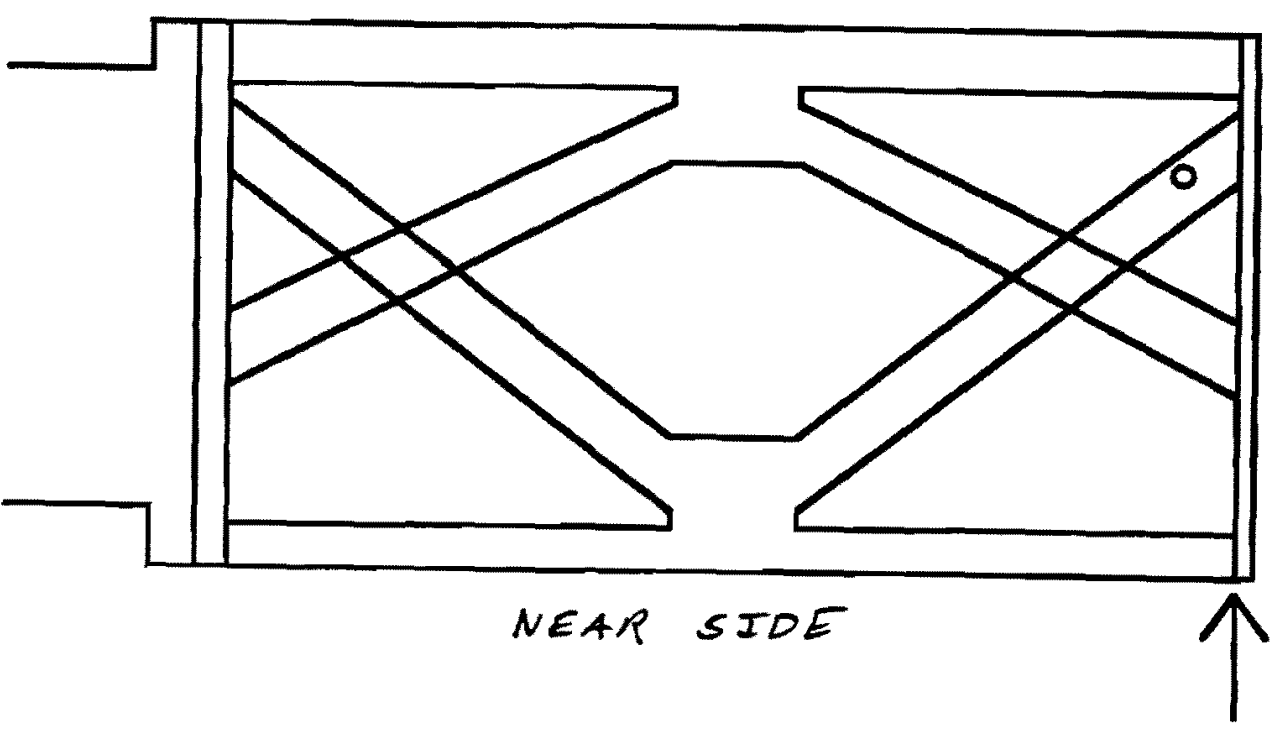


Data from "Fourth MFH Model, 8-23-88"

Gage *2, Bottom Strut, Near Front Plate

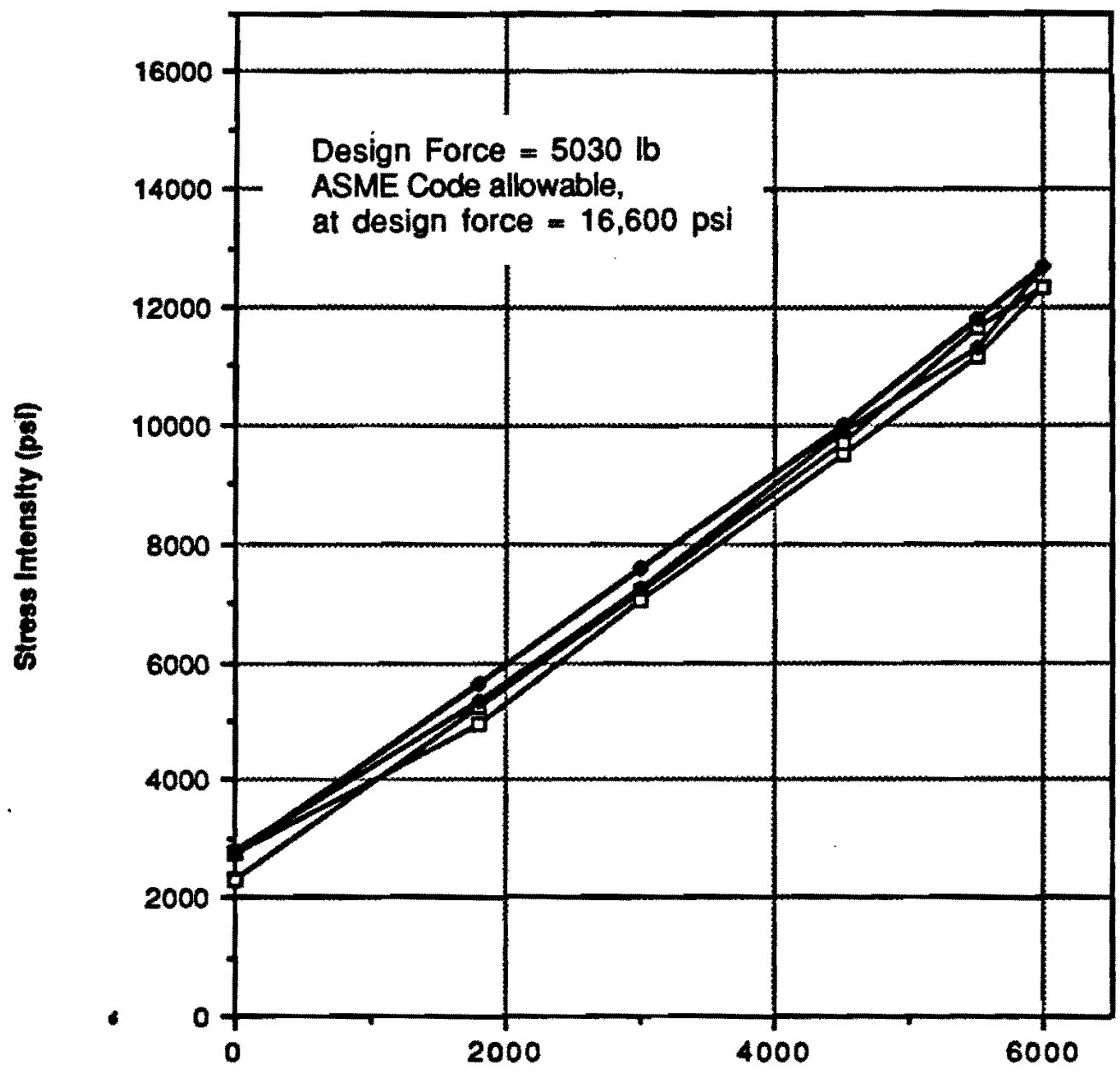

- First Load

- Second Load

- First Unload

- Second Unload

Jack Force (lb)

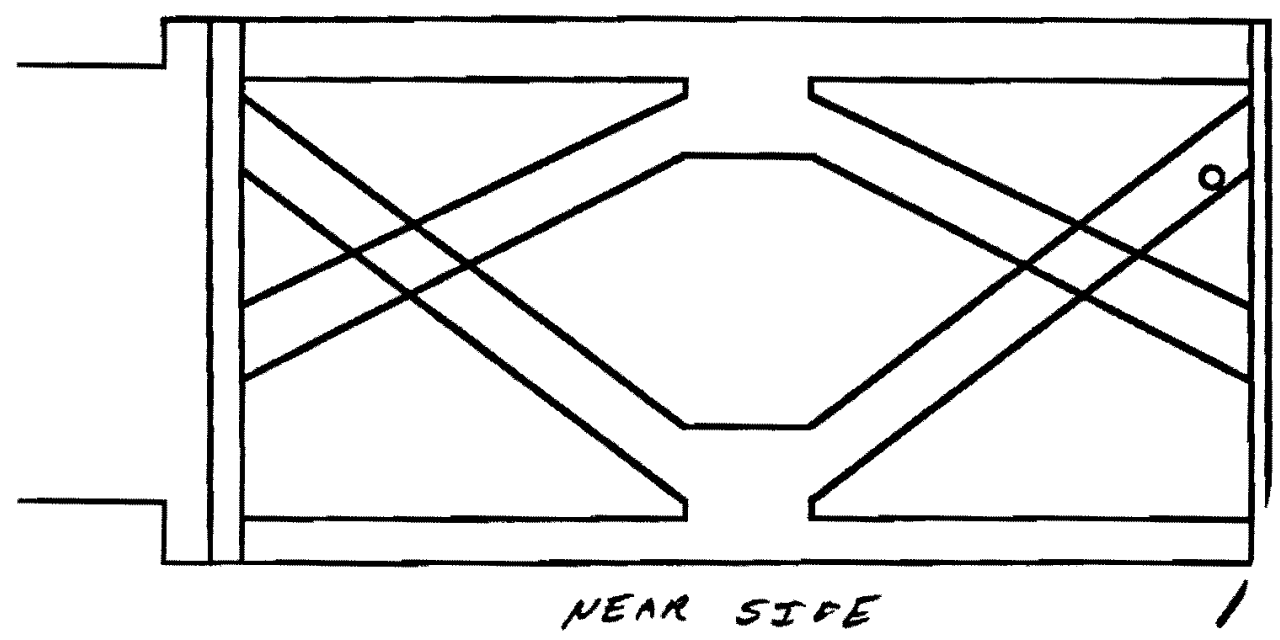


Data from "Fourth MFH Model, 8-23-88"

Gage \#3, O.R. Side Flange, Near Front Plate

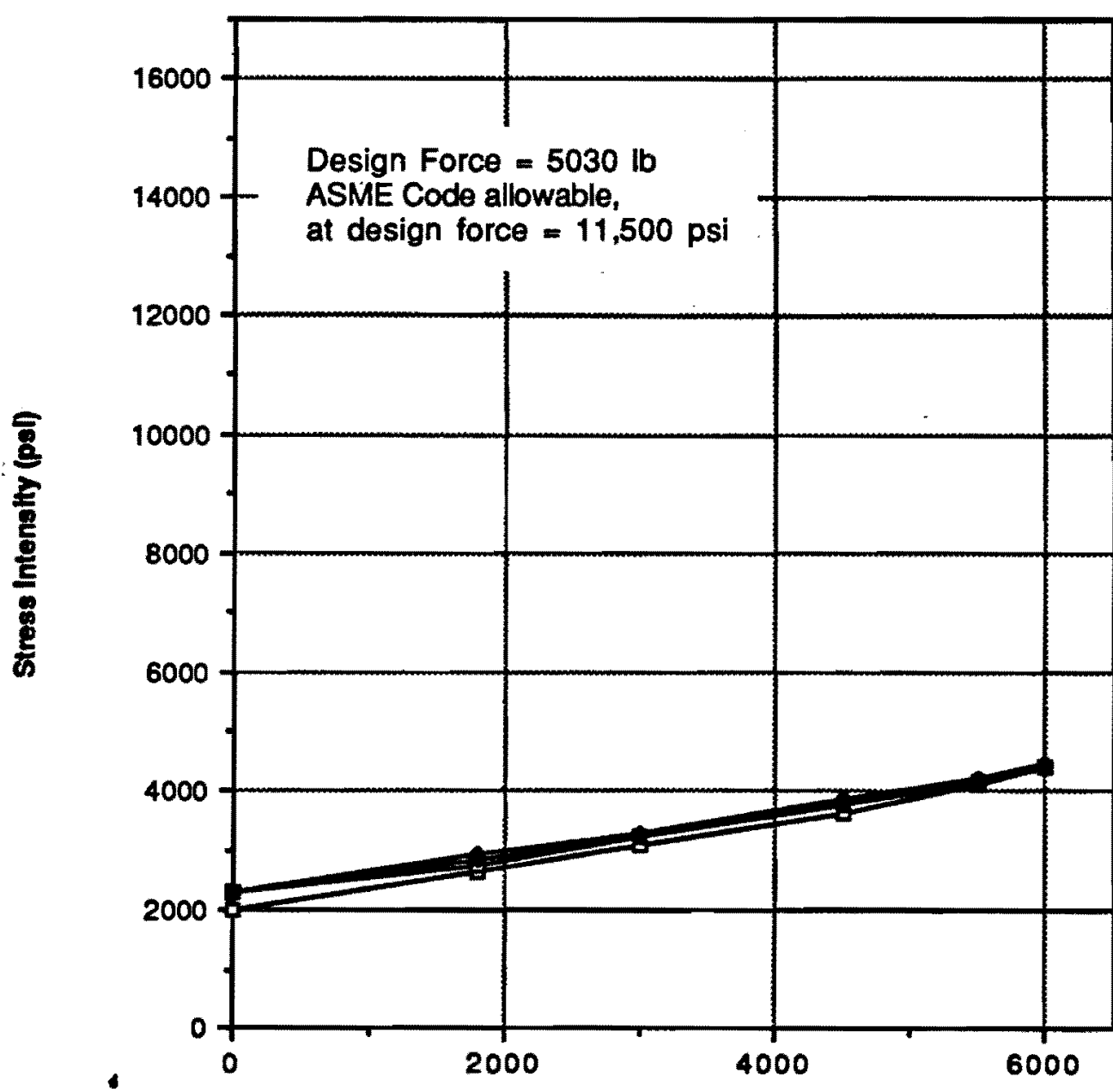

- First Load

- Second Load

- First Unload

- Second Unioad

Jack Force (lb)

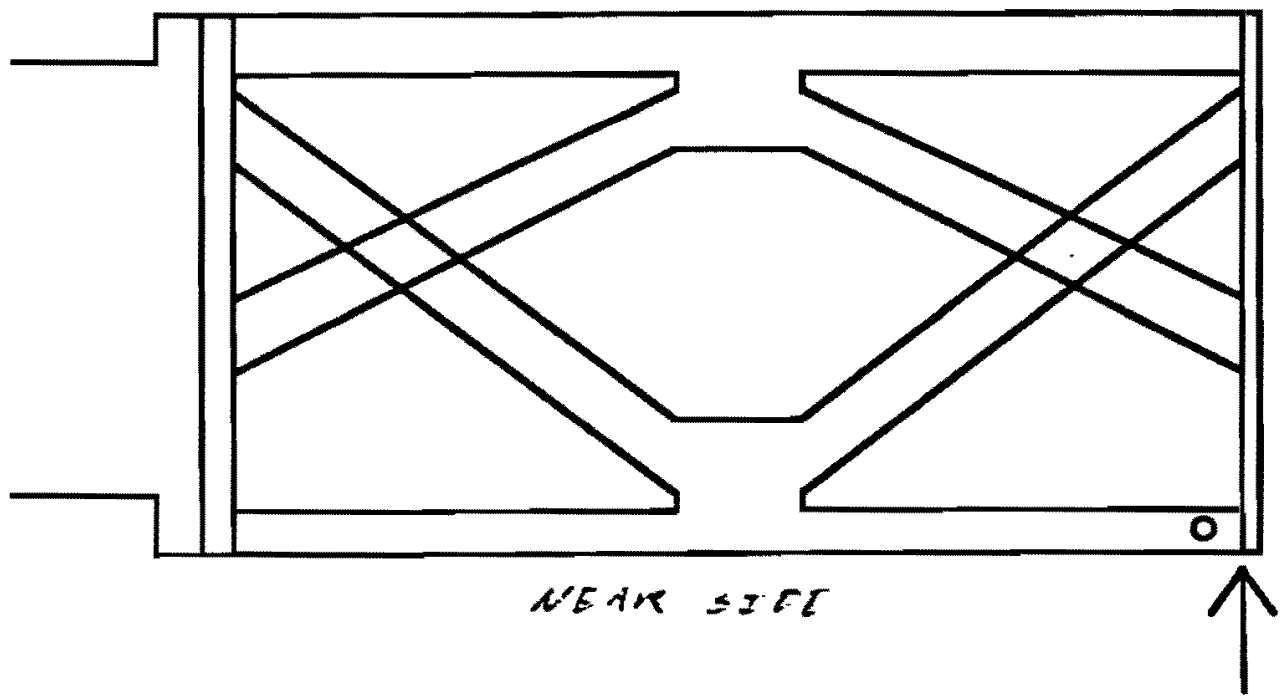


Data from "Fourth MFH Model, 8-23-88"

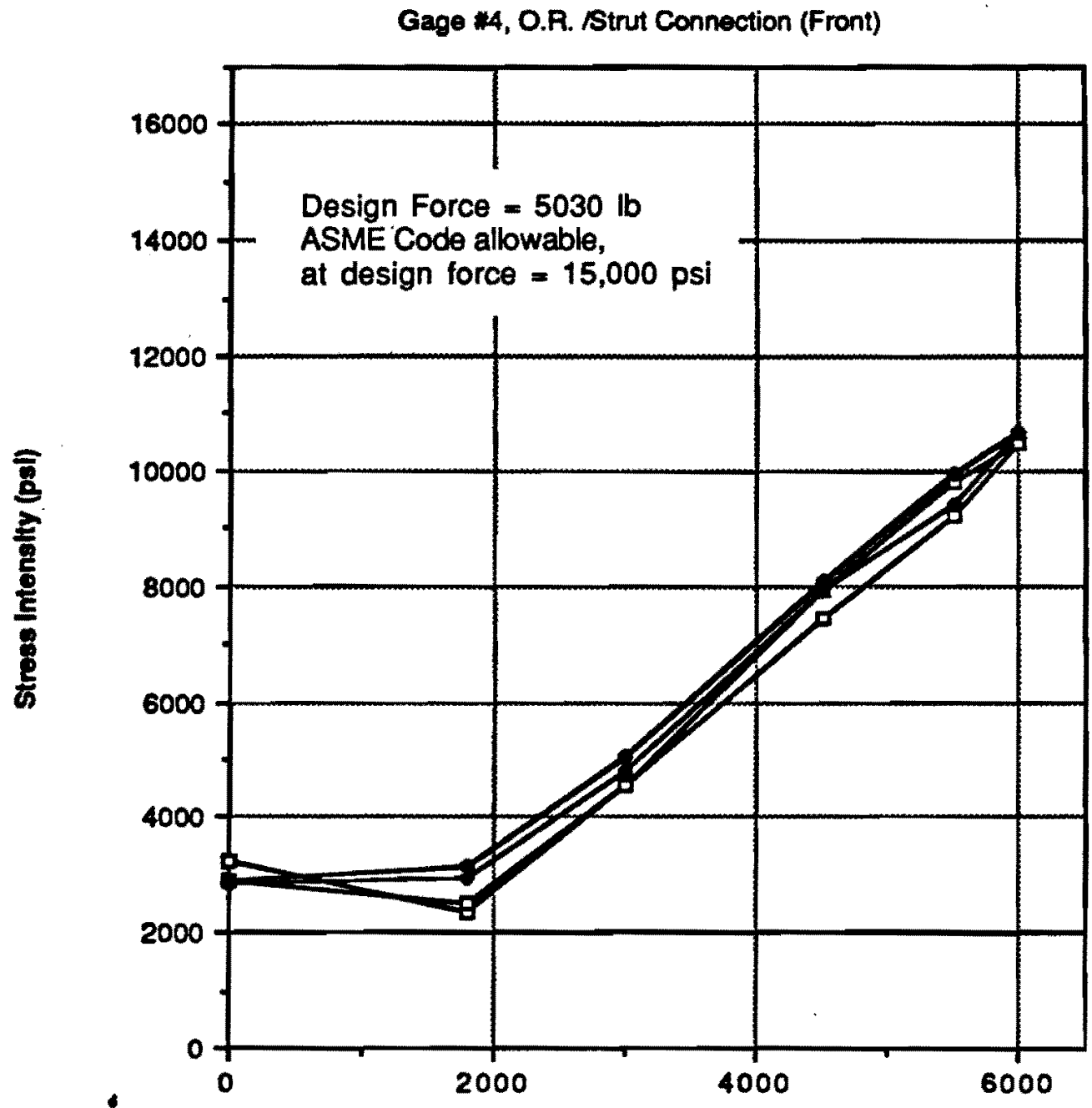

- First Load

- Second Load

- First Unload

- Second Unload

Jack Force (lb)

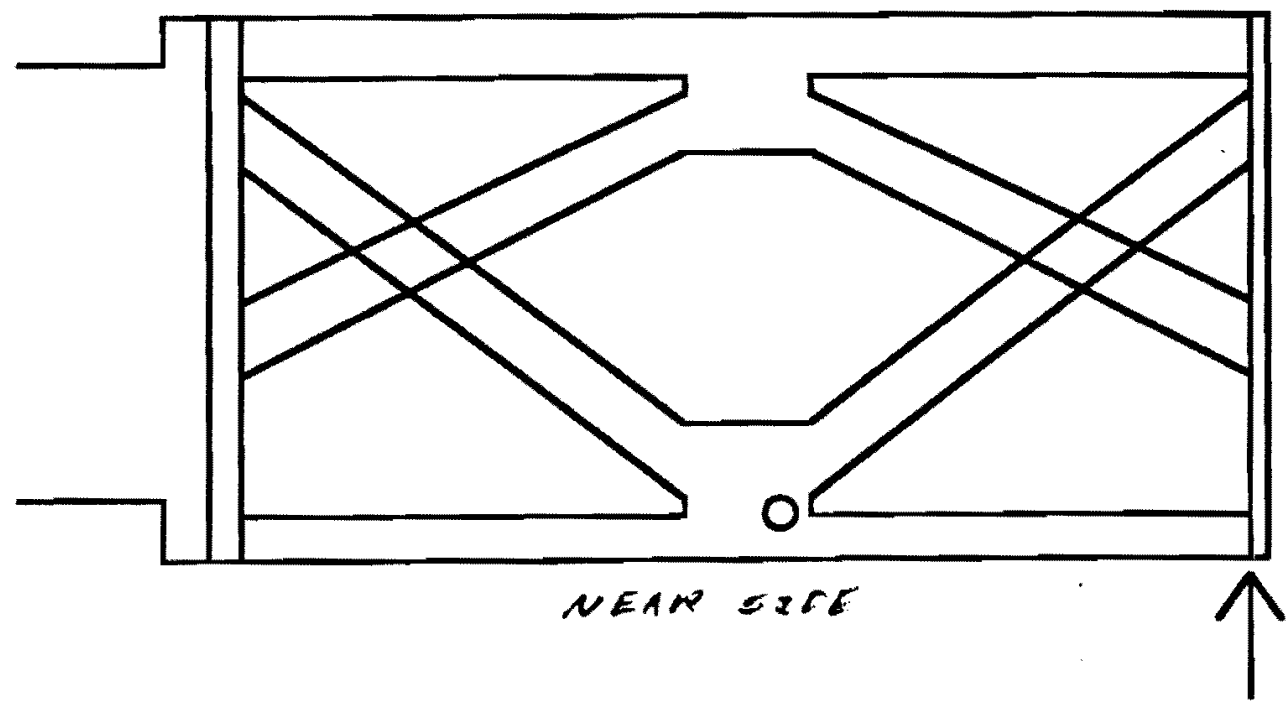


Data from "Fourth MFH Model, 8-23-88"

Gage *5, O.R./Strut Connection (Back)

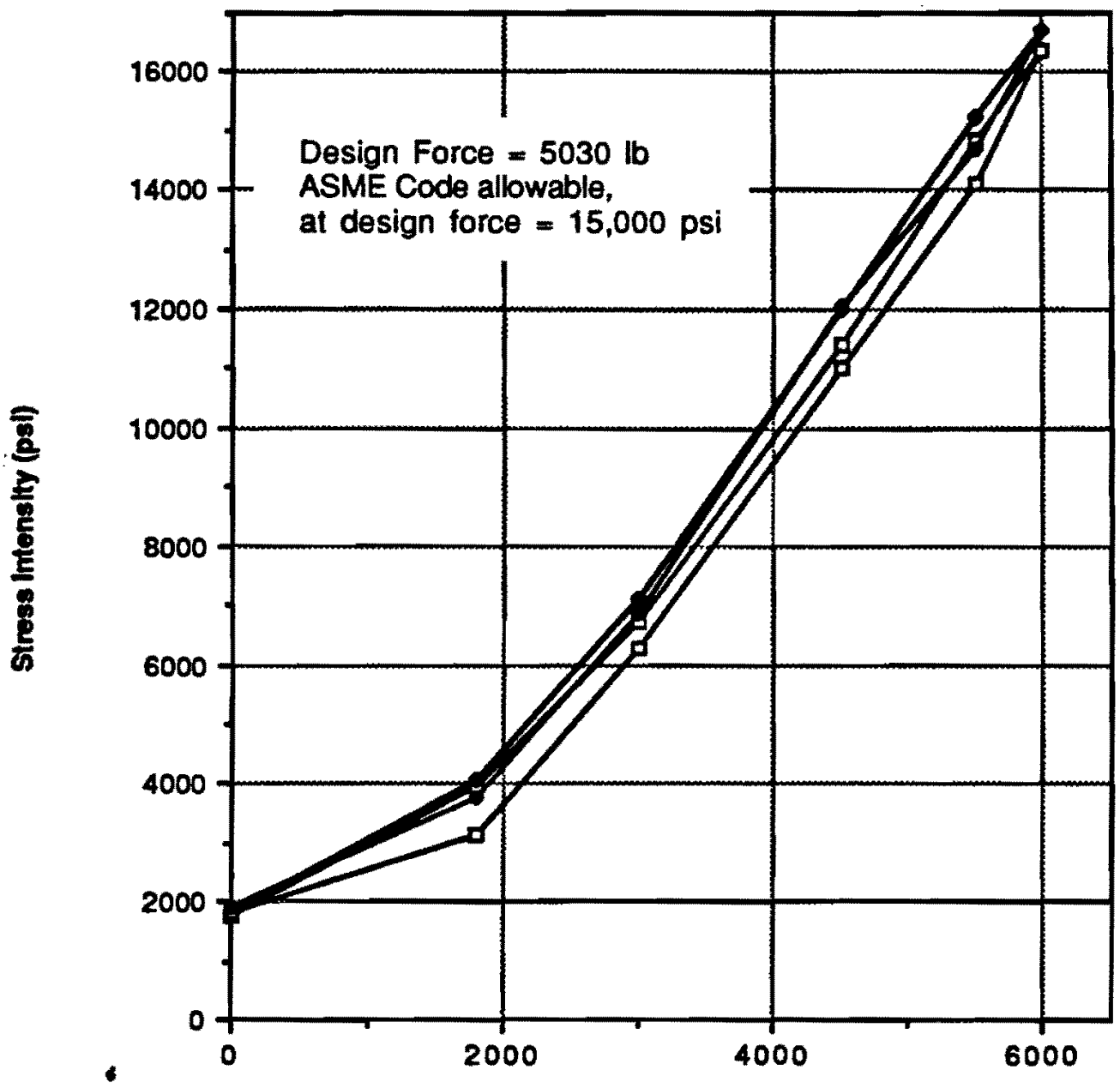

- First Load

- Second Load

$\rightarrow$ First Unload

- Second Unload

Jack Force (lb)

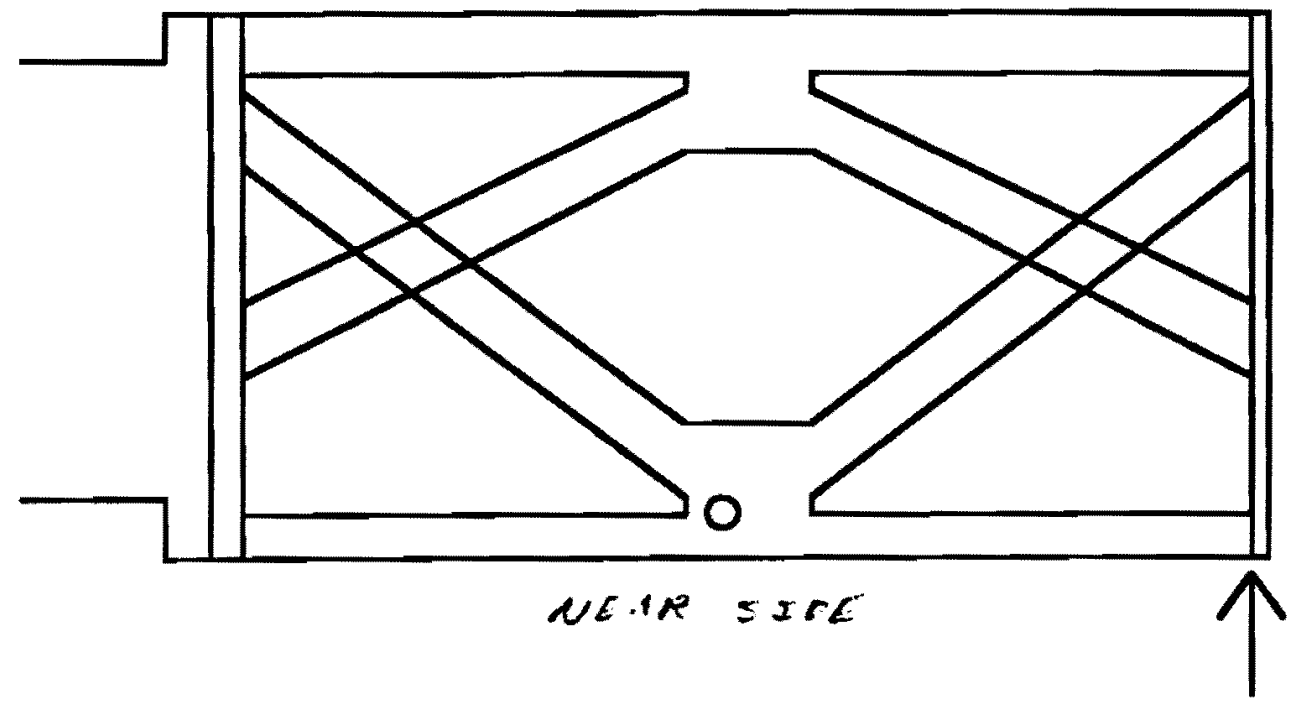


Data from "Fourth MFH Model, 8-23-88"

Gage 6 , Top of Strut, Near Front Plate

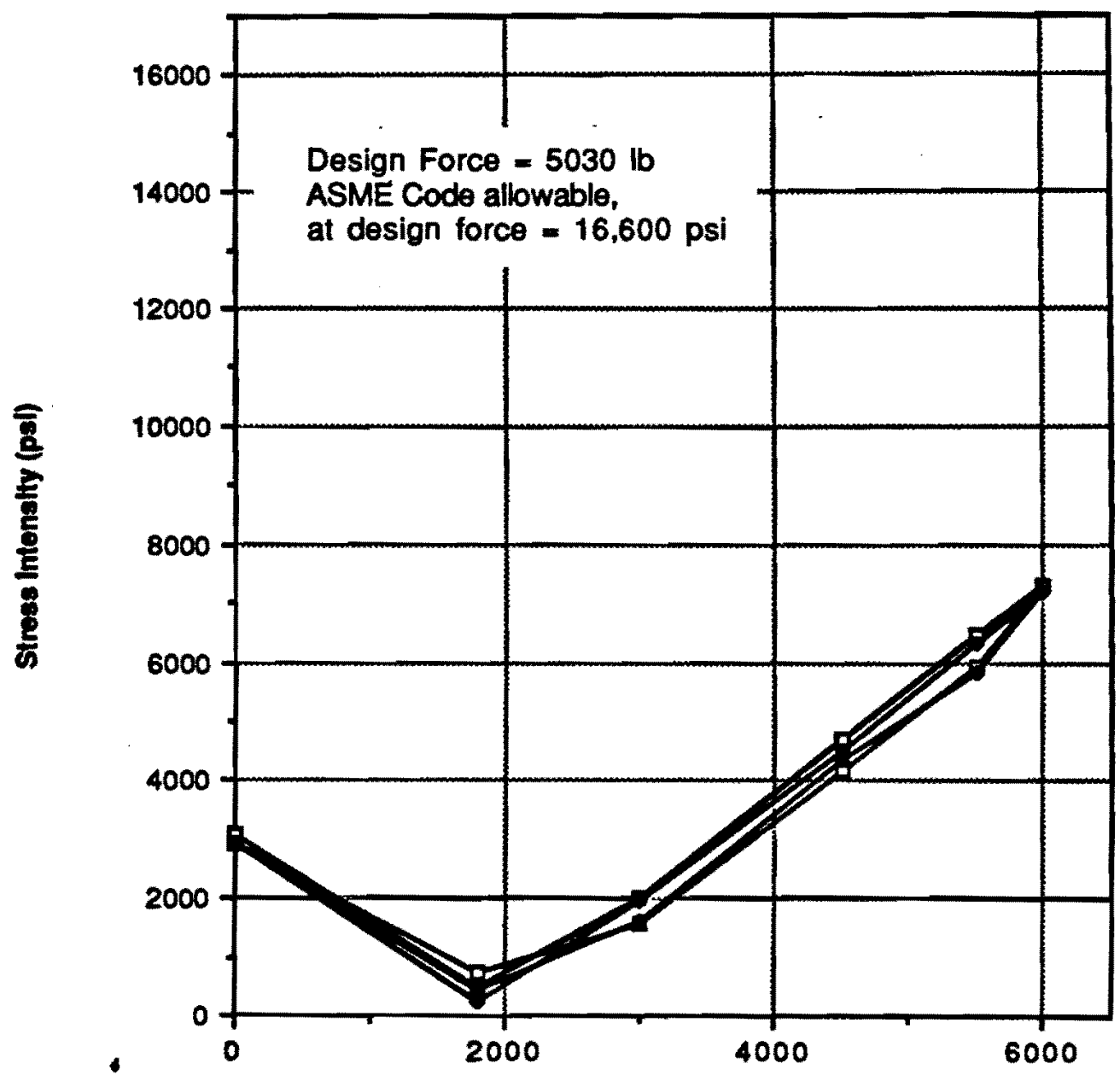

a- First Load

- Second Load

- First Unload

- Second Unload

Jack Force (lb)

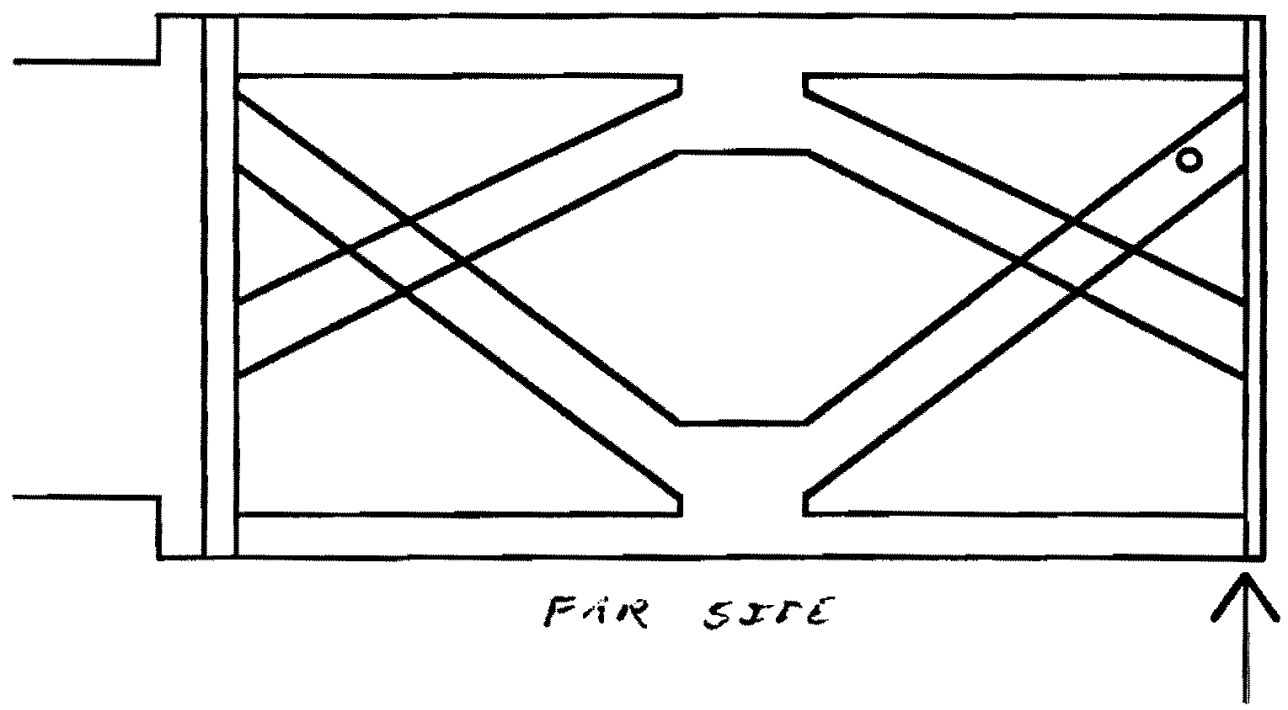


Data from "Fourth MFH Model, 8-23-88"

Gage \$7, Bottom Strut, Near Front Plate

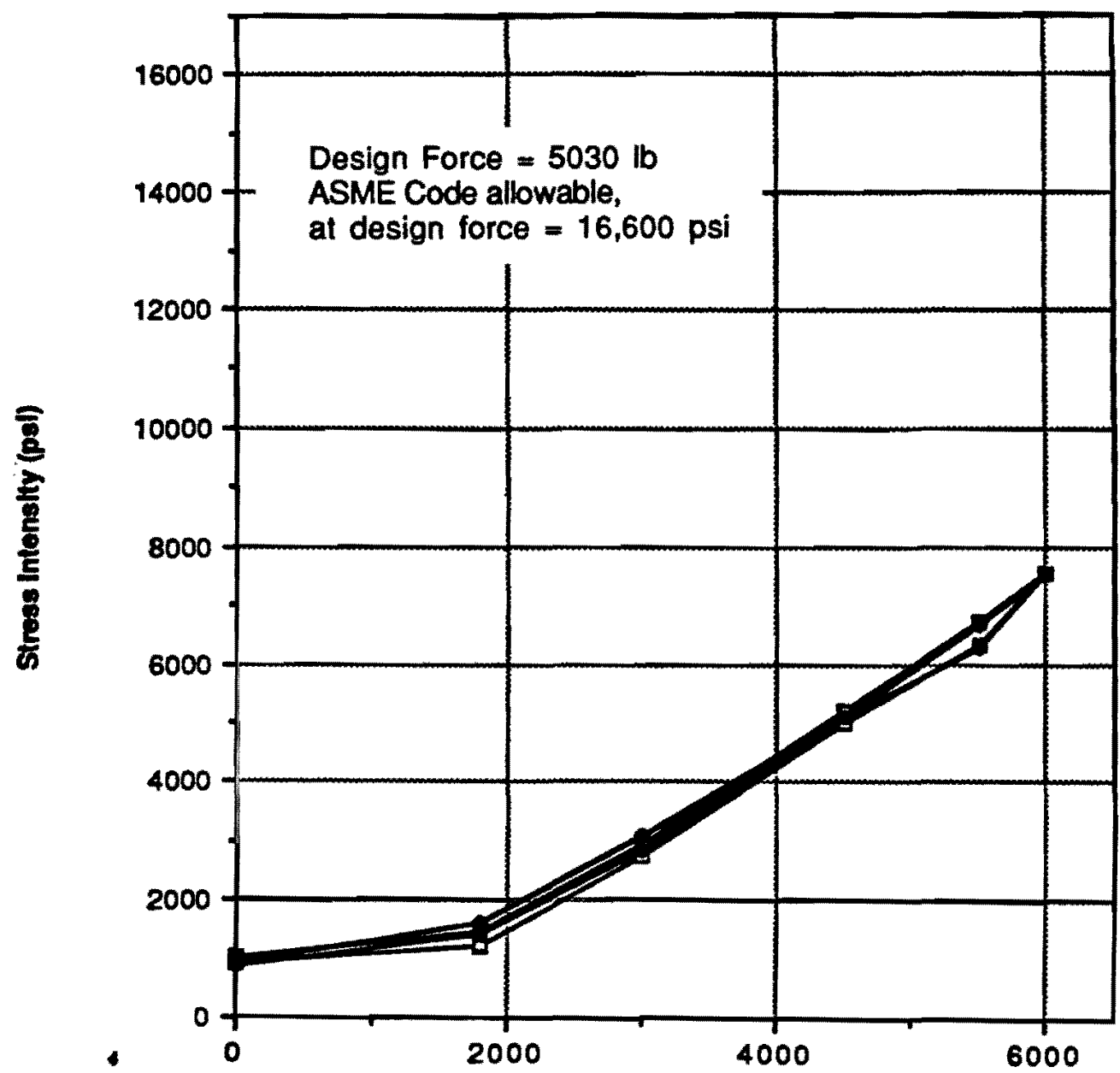

- First Load

- Second Load

- First Unload

- Second Unioad

Jack Foree (lb)

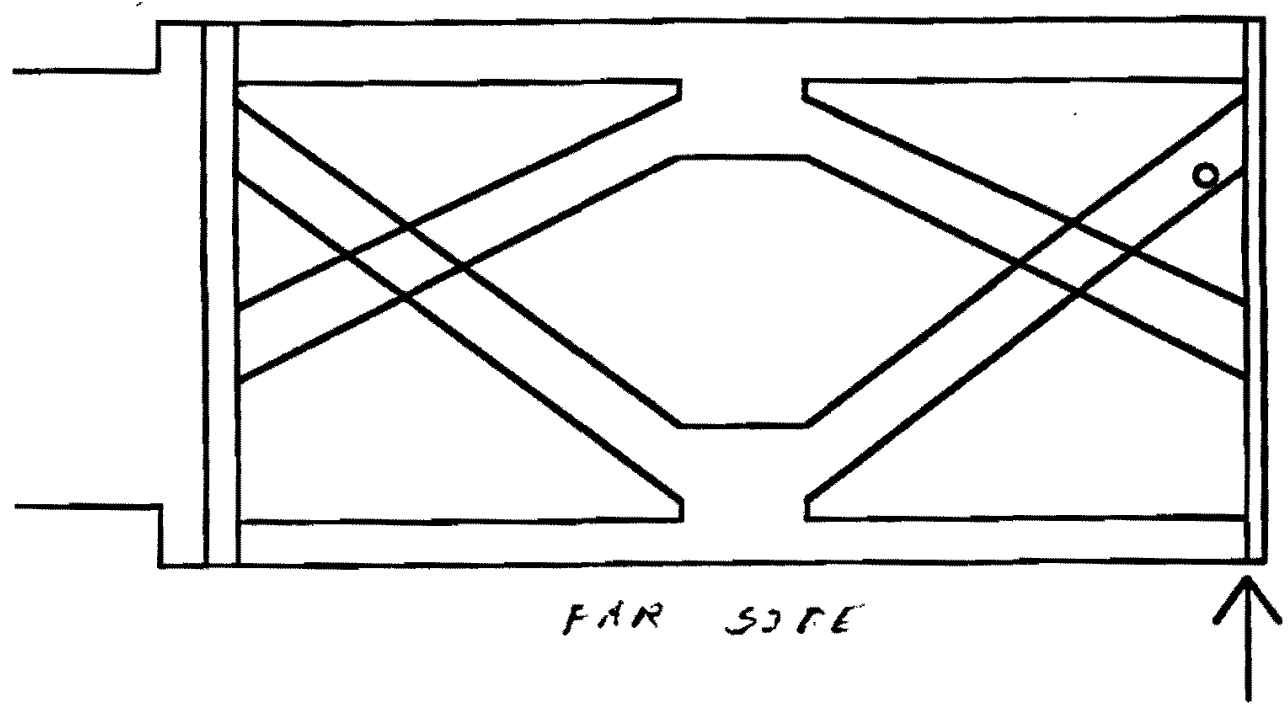


Data from "Fourth MFH Model, 8-23-88"

Gage \#8, O.R. Side Flange, Near Front Plate

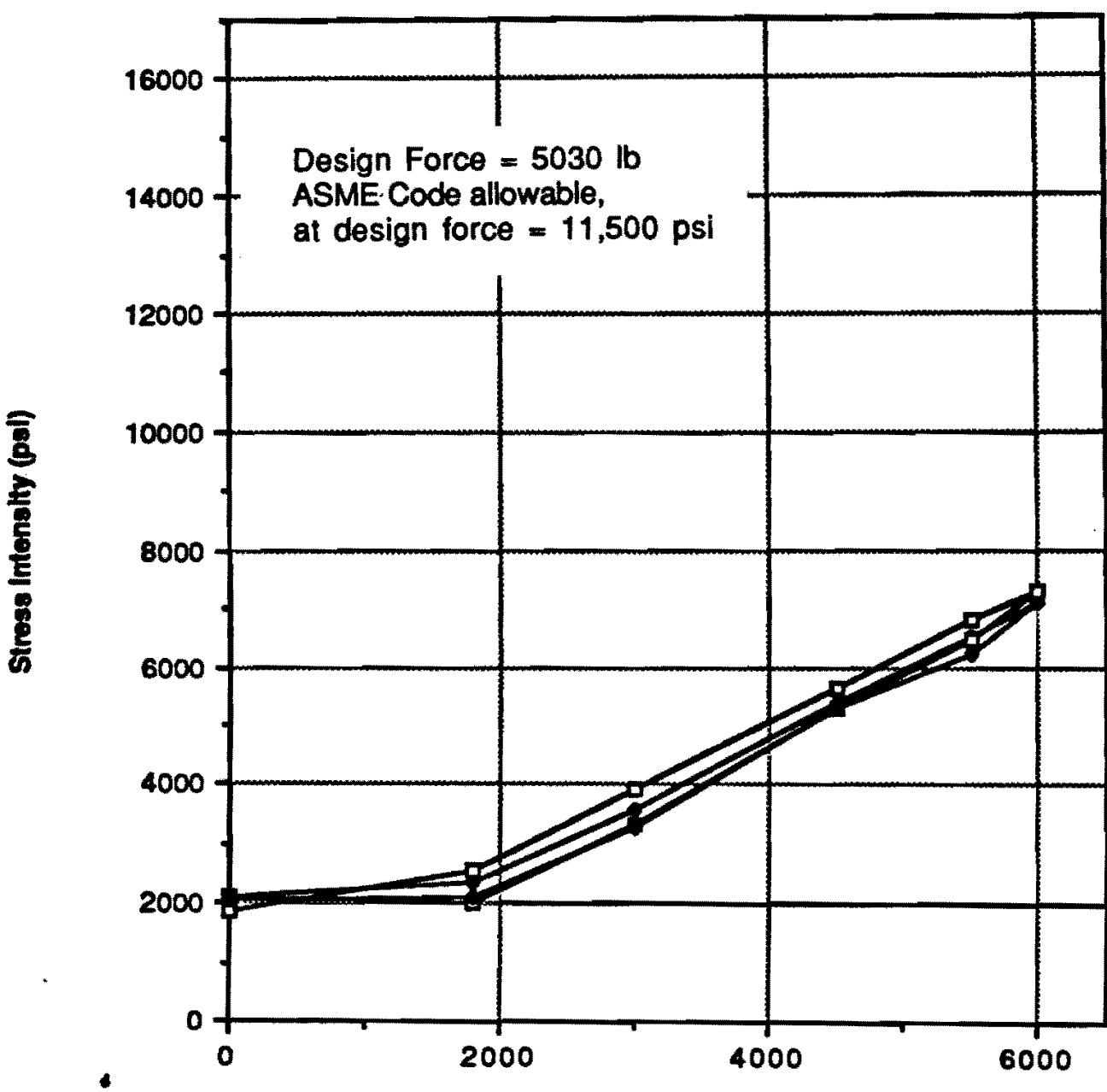

- First Load

- Second Load

- First Unload

- Second Unload

Jack Force (Ib)

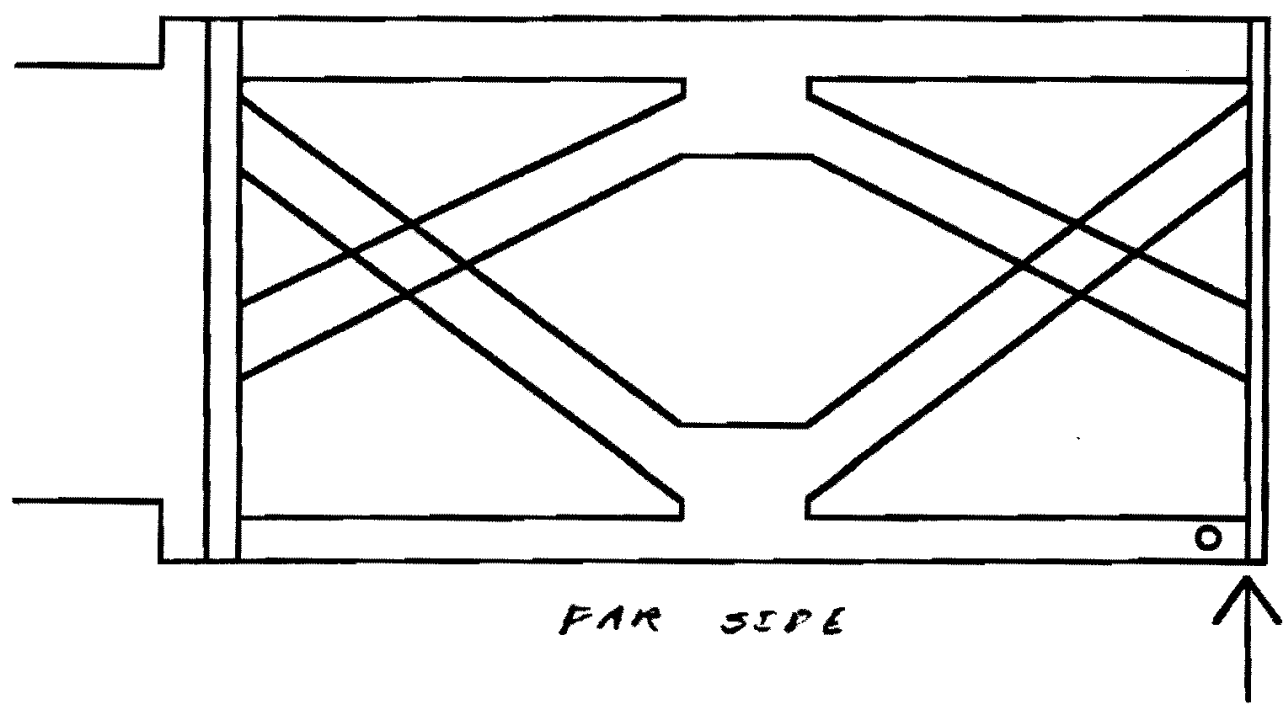


Data from "Fourth MFH Model, 8-23-88"

Gage *9, O.R./Strut Connection (Front)

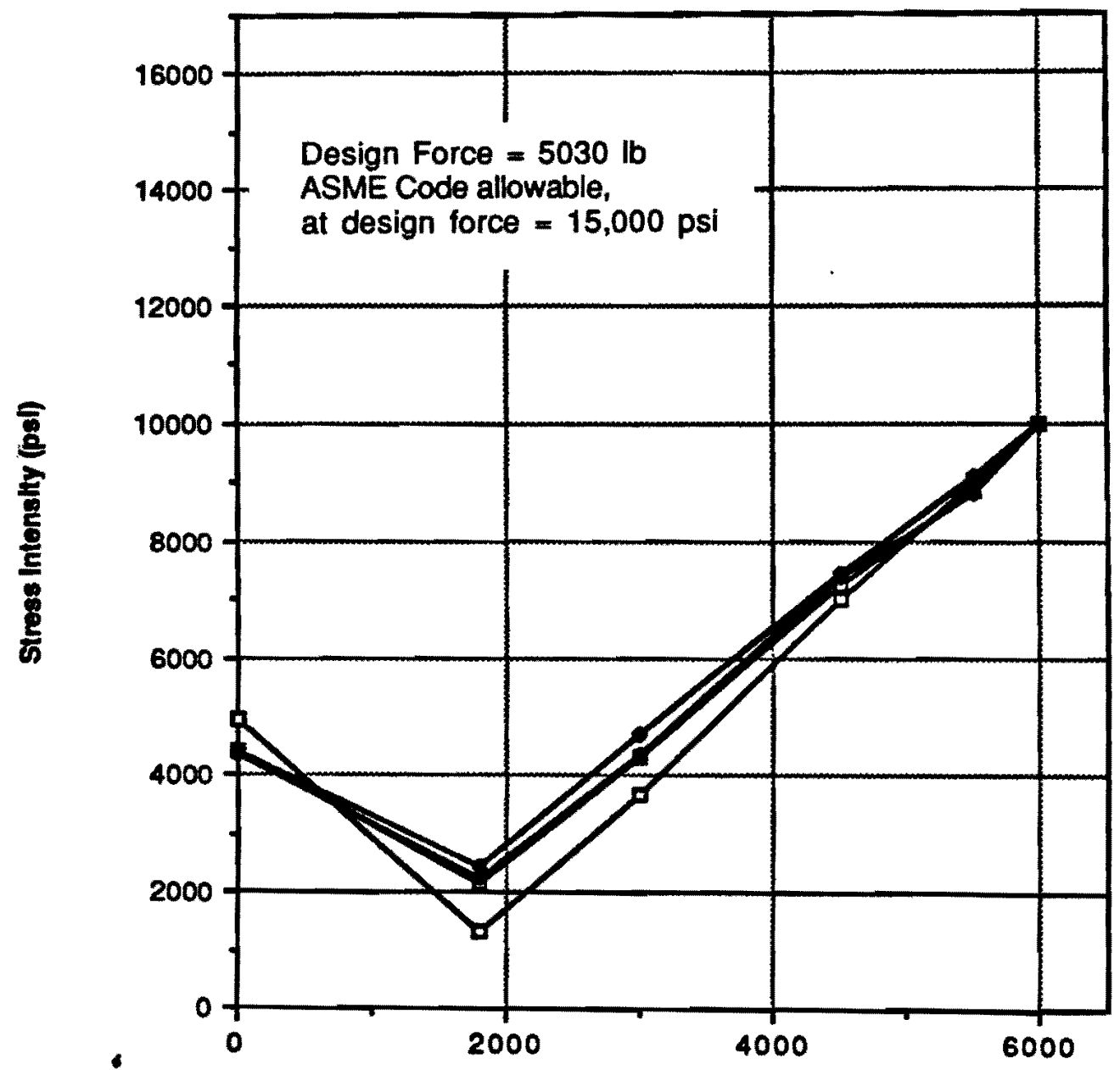

- First Load

- Second Load

- First Unload

- Second Unload

Jack Force (lb)

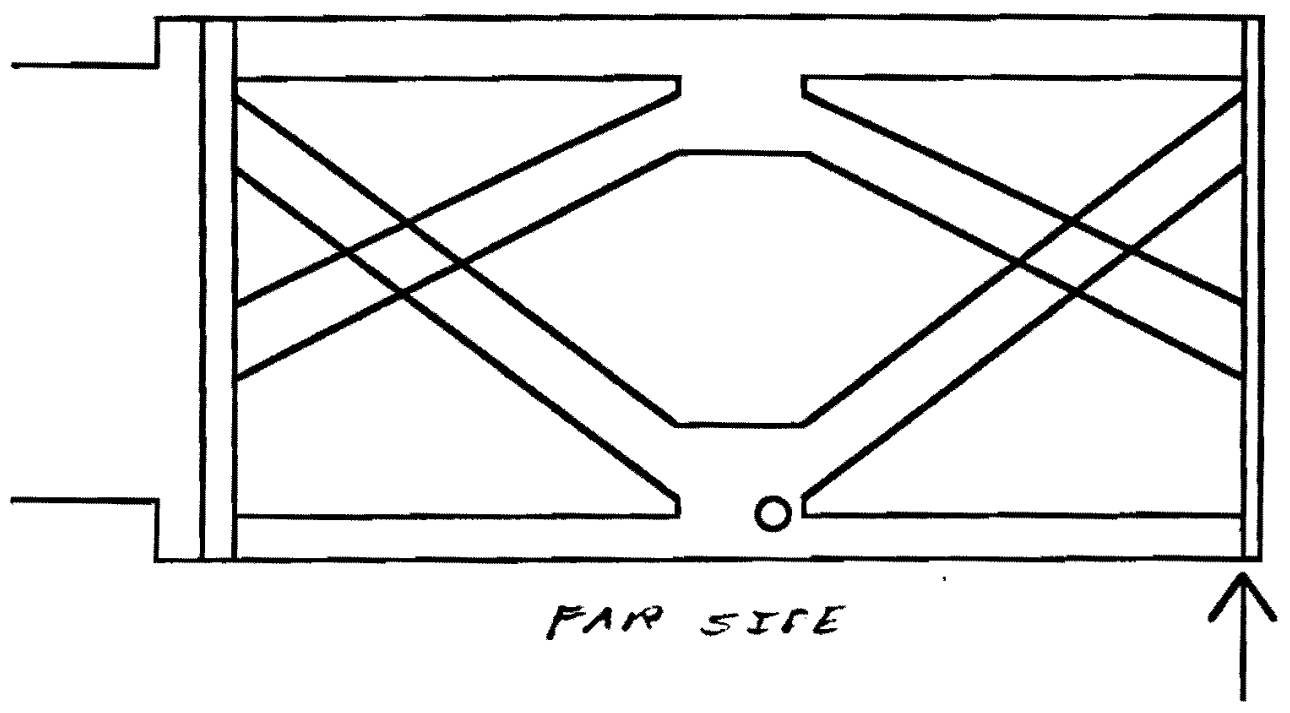


Data from "Fourth MFH Model, 8-23-88"

Gage : 10, O.R./Strut Connection (Back)

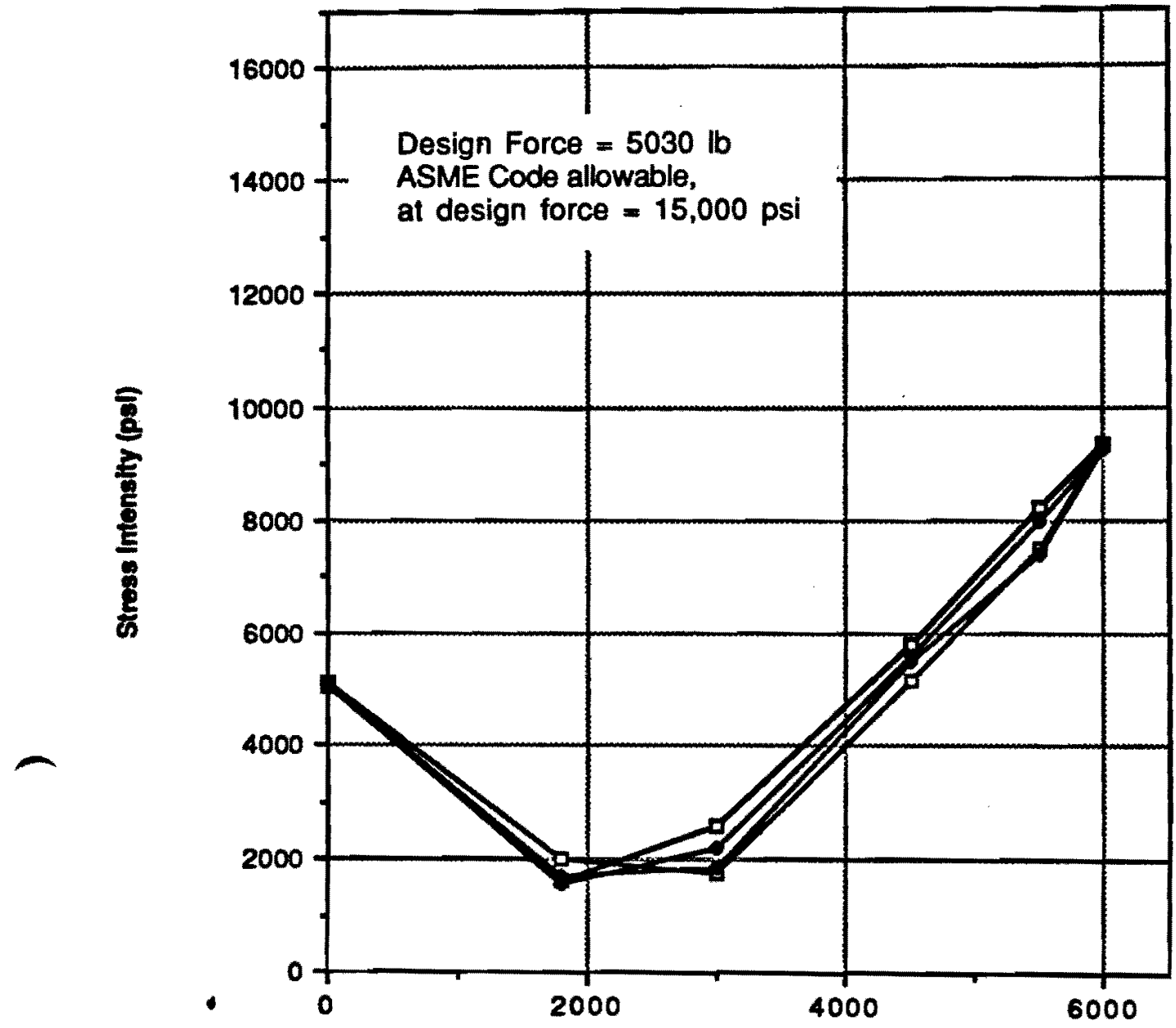

- First Load

- Second Load

- First Unload

- Second Unload

Jack Foree (16)

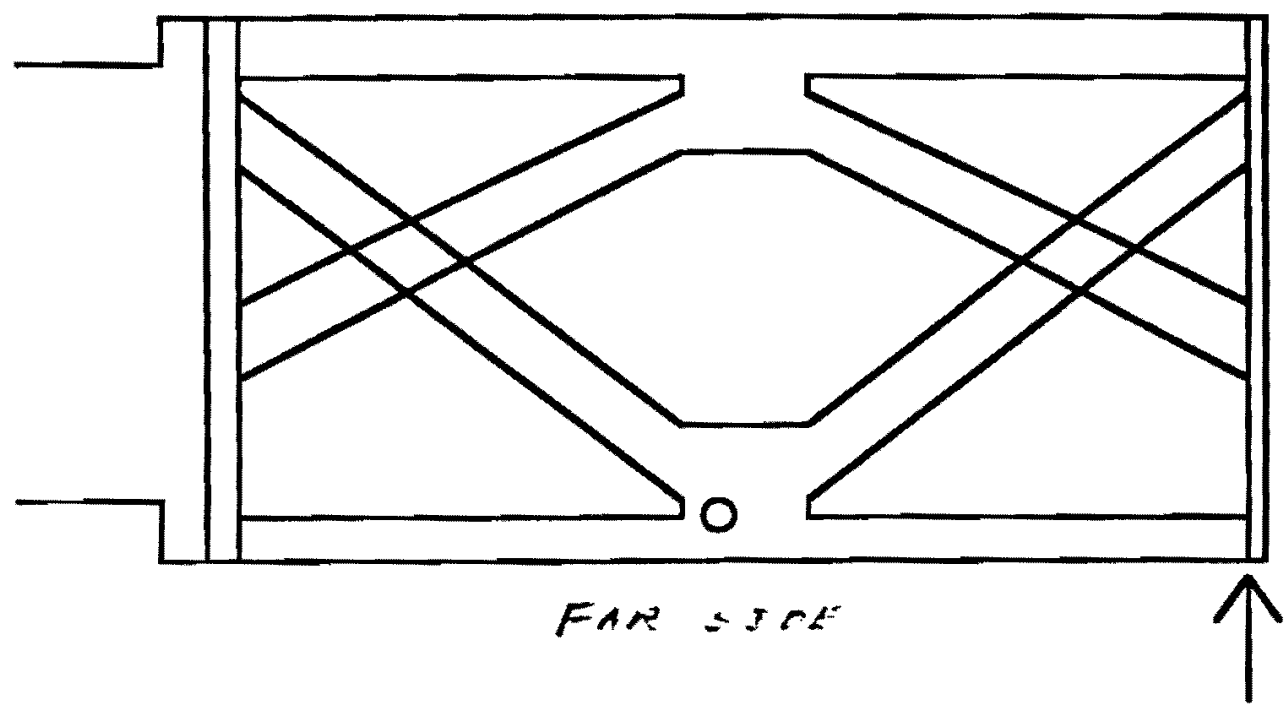


Fourth MFH Model, Tested 8-23-88

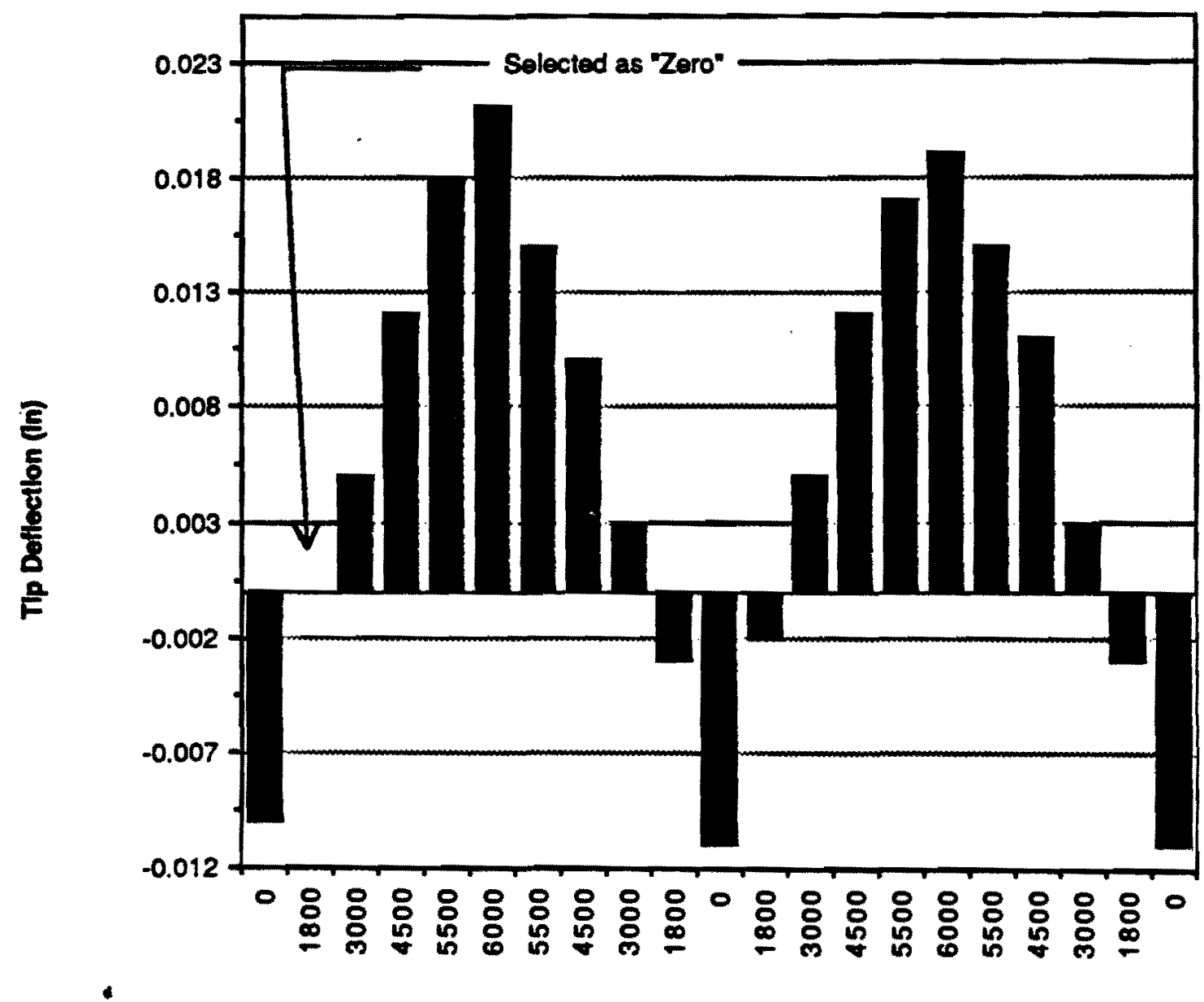

Jack Force (Ib) 
MFH Fourth Model, Tested August 23, 1988

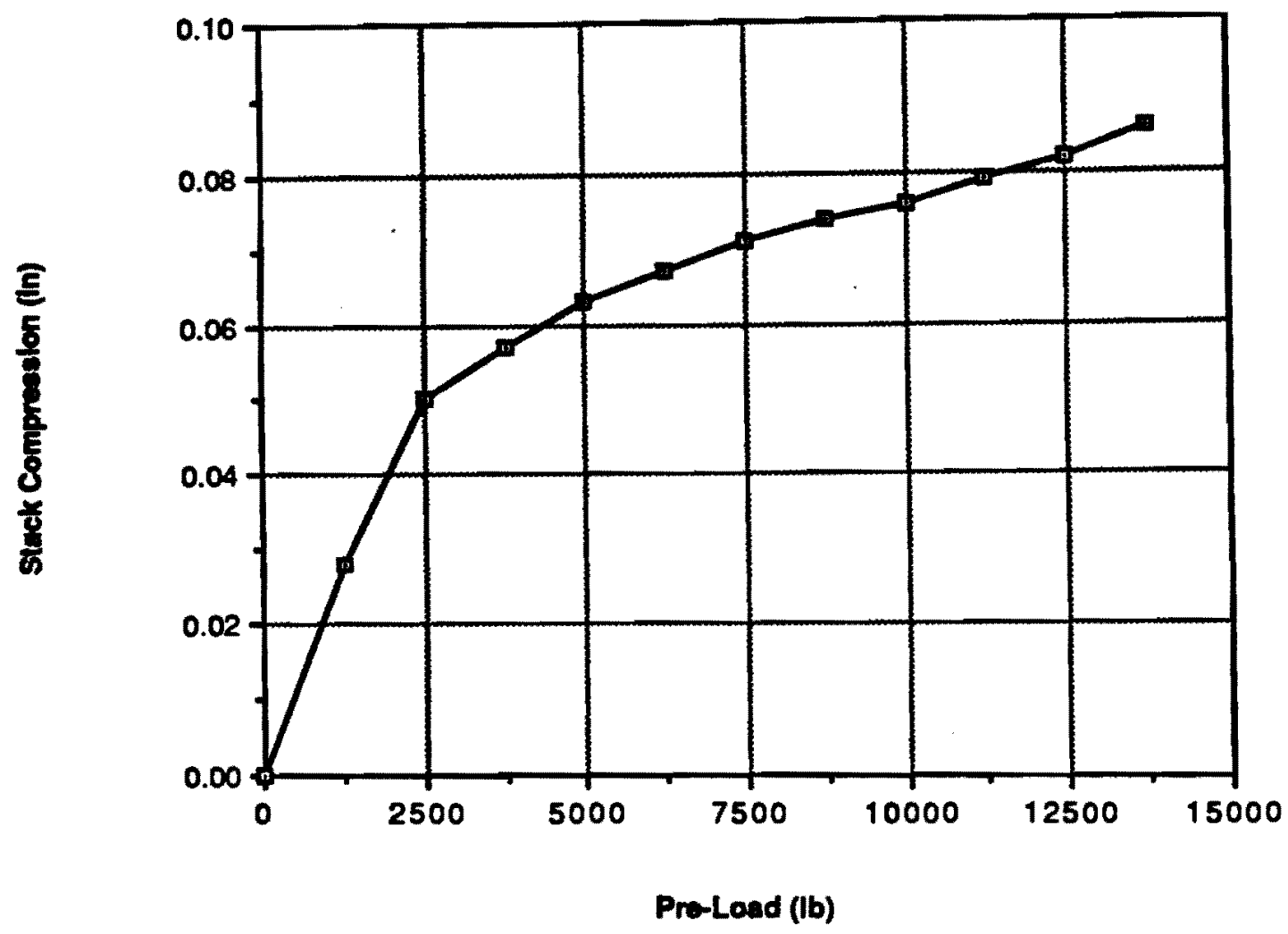

Spring Constant of Stack (Above $5000 \mathrm{lb}$ )

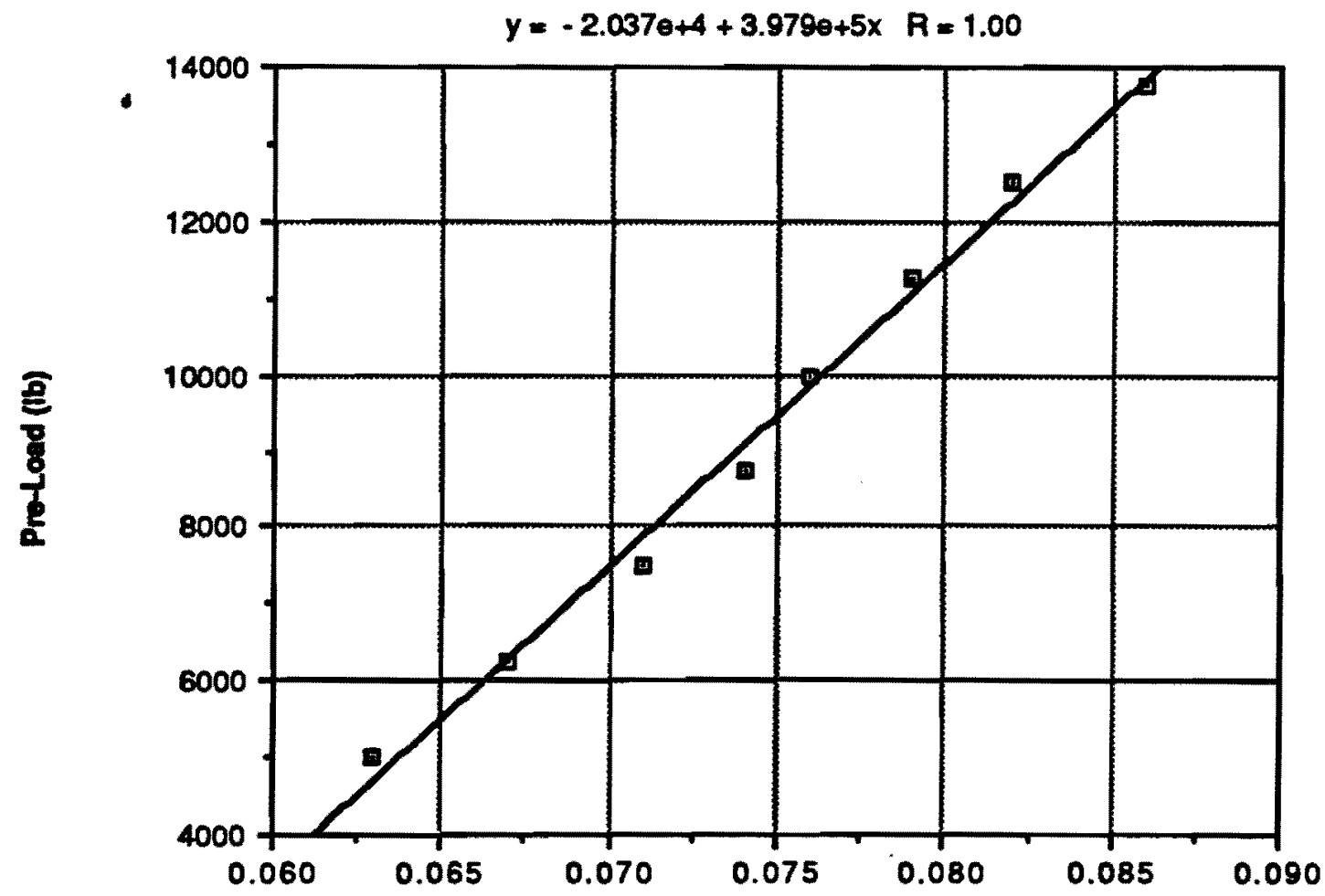

Stack Compression (In) 
Appendix 5

Data 
MFH Fourth Model Test, August 23, 1988

Dial Indicator Readings (W/2500 lb of Bricks) Deflections (W/2500 lb of Bricks)

Jack Force North Ctr North Tip South Cir South Tip North Cir North Tip South Cir South Tip Average Ctr Average Tip
(lb)
(in)
(in)
(in)
(in)
(in)
(in)
(in)
(in)
(in)
(in)

\begin{tabular}{rrrrrrrrrrr}
\hline 0 & 0.223 & 0.475 & 0.222 & 0.475 & -0.005 & -0.010 & -0.004 & -0.009 & .0 .004 & -0.010 \\
\hline 1800 & 0.218 & 0.465 & 0.218 & 0.466 & 0.000 & 0.000 & 0.000 & 0.000 & 0.000 & 0.000 \\
\hline 3000 & 0.216 & 0.460 & 0.216 & 0.461 & 0.002 & 0.005 & 0.002 & 0.005 & 0.002 & .0 .005 \\
4500 & 0.212 & 0.453 & 0.212 & 0.454 & 0.006 & 0.012 & 0.006 & 0.012 & 0.006 & 0.012 \\
5500 & 0.210 & 0.448 & 0.209 & 0.448 & 0.008 & 0.017 & 0.009 & 0.018 & 0.009 & 0.018 \\
6000 & 0.209 & 0.445 & 0.207 & 0.445 & 0.009 & 0.020 & 0.011 & 0.021 & 0.010 & 0.021 \\
5500 & 0.211 & 0.452 & 0.209 & 0.449 & 0.008 & 0.013 & 0.009 & 0.018 & 0.008 & 0.015 \\
4500 & 0.213 & 0.457 & 0.212 & 0.454 & 0.006 & 0.008 & 0.006 & 0.012 & 0.006 & 0.010 \\
3000 & 0.216 & 0.464 & 0.216 & 0.462 & 0.002 & 0.001 & 0.002 & 0.005 & 0.002 & 0.003 \\
1800 & 0.220 & 0.471 & 0.219 & 0.467 & -0.002 & -0.005 & -0.001 & -0.001 & -0.001 & -0.003 \\
0 & 0.223 & 0.478 & 0.222 & 0.474 & -0.005 & -0.013 & -0.004 & -0.008 & -0.004 & -0.011 \\
1800 & 0.219 & 0.469 & 0.218 & 0.465 & -0.001 & -0.004 & 0.000 & 0.001 & -0.001 & -0.002 \\
3000 & 0.216 & 0.463 & 0.215 & 0.459 & 0.002 & 0.002 & 0.003 & 0.007 & 0.003 & 0.005 \\
4500 & 0.213 & 0.456 & 0.211 & 0.452 & 0.005 & 0.009 & 0.007 & 0.014 & 0.006 & 0.012 \\
5500 & 0.210 & 0.452 & 0.208 & 0.446 & 0.008 & 0.014 & 0.010 & 0.020 & 0.009 & 0.017 \\
6000 & 0.209 & 0.449 & 0.206 & 0.444 & 0.009 & 0.016 & 0.012 & 0.023 & 0.011 & 0.019 \\
5500 & 0.211 & 0.448 & 0.209 & 0.453 & 0.007 & 0.017 & 0.009 & 0.014 & 0.008 & 0.015 \\
4500 & 0.213 & 0.457 & 0.211 & 0.453 & 0.005 & 0.008 & 0.007 & 0.013 & 0.006 & 0.011 \\
3000 & 0.217 & 0.465 & 0.216 & 0.461 & 0.002 & 0.000 & 0.002 & 0.005 & 0.002 & 0.003 \\
1800 & 0.219 & 0.471 & 0.218 & 0.466 & -0.001 & -0.005 & 0.000 & 0.000 & -0.001 & -0.003 \\
0 & 0.223 & 0.478 & 0.222 & 0.474 & -0.005 & -0.013 & -0.004 & -0.008 & -0.005 & -0.011
\end{tabular}




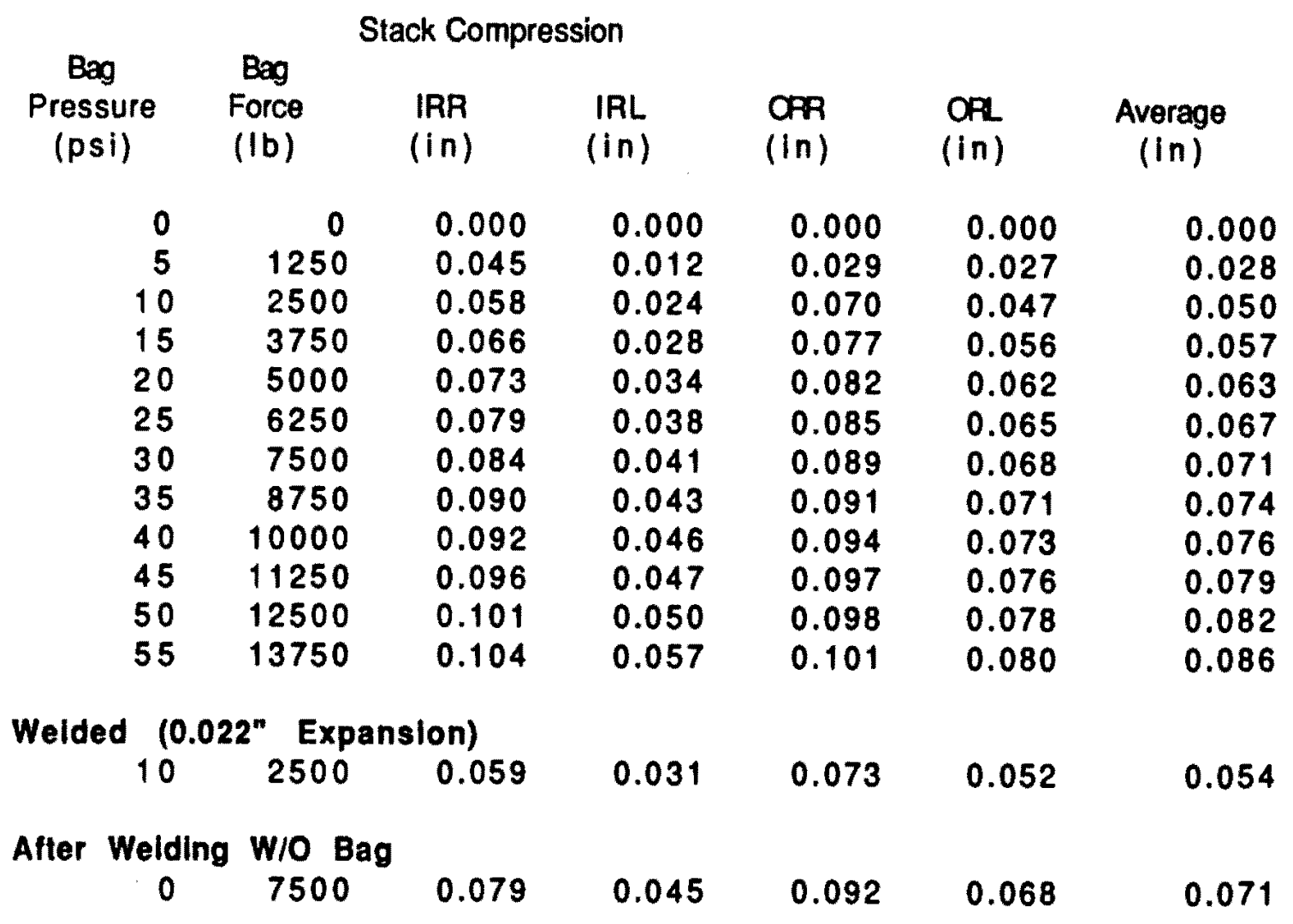


Pre-Lood Stress (Before and After Bag Removal)

\begin{tabular}{|c|c|c|c|c|c|c|c|c|c|c|c|c|}
\hline & $\begin{array}{l}\text { Measured } \\
\text { Strains } \\
(x 10 \text { e } 6)\end{array}$ & $\begin{array}{c}\text { Measured } \\
\text { Strains } \\
(x 1006)\end{array}$ & $\begin{array}{c}\text { Adjust for } \\
\text { Drlft } \\
(x 10 \otimes 6)\end{array}$ & $\begin{array}{l}\text { Adjusted } \\
\text { Straln } \\
(x 1006)\end{array}$ & $\begin{array}{l}\text { Stress } \\
\text { Intensity } \\
\text { (ps|) }\end{array}$ & $\begin{array}{l}\text { Max Princ } \\
\text { Stress } \\
\text { (psi) }\end{array}$ & $\begin{array}{c}\text { Min Princ } \\
\text { Stress } \\
\text { (psi) }\end{array}$ & $\begin{array}{c}\text { Theta } \\
\text { (degrees) }\end{array}$ & $\begin{array}{l}\text { Maximun } \\
\text { Shear } \\
(p s i)\end{array}$ & $\begin{array}{l}\text { X-DIr } \\
\text { Stress } \\
\text { (psi) }\end{array}$ & $\begin{array}{l}Y-D I r \\
\text { Stress } \\
(p \& I)\end{array}$ & $\begin{array}{c}X Y \\
\text { Shear } \\
(p \& 1)\end{array}$ \\
\hline $\begin{array}{l}\text { \# } 1 \\
\text { Truss gage top } \\
\text { near front pl. }\end{array}$ & $\begin{array}{r}141 \\
-198 \\
164\end{array}$ & $\begin{array}{r}143 \\
-188 \\
157\end{array}$ & & $\begin{array}{r}-2 \\
-10 \\
7\end{array}$ & 428 & 146 & -281 & 44.0 & 214 & .60 & .75 & 214 \\
\hline$\# 2$ & 343 & 310 & & 33 & & & & & & & • & \\
\hline $\begin{array}{l}\text { Truss gage bot } \\
\text { near tront pl. }\end{array}$ & $\begin{array}{r}-203 \\
198\end{array}$ & $\begin{array}{r}-199 \\
187\end{array}$ & & $\begin{array}{l}-4 \\
11\end{array}$ & 1007 & 1007 & 71 & -11.9 & 468 & 967 & 111 & .189 \\
\hline$\because 3$ & .29 & .15 & & -14 & & & & & & & & \\
\hline $\begin{array}{l}\text { O.R. side flange } \\
\text { near tront pl. }\end{array}$ & $\begin{array}{r}18 \\
.38\end{array}$ & $\begin{array}{r}7 \\
-27\end{array}$ & & $\begin{array}{r}11 \\
-11\end{array}$ & 686 & 154 & -532 & -26.8 & 343 & 15 & .392 & -277 \\
\hline * 4 & 194 & 186 & & 8 & & & & : & & & & \\
\hline $\begin{array}{c}\text { O.R. Truss } \\
\text { Joint (Front) }\end{array}$ & $\begin{array}{l}175 \\
239\end{array}$ & $\begin{array}{l}148 \\
229\end{array}$ & & $\begin{array}{l}27 \\
10\end{array}$ & 869 & 869 & 344 & .27 .3 & 262 & 759 & 454 & -214 \\
\hline$\# 5$ & 273 & 254 & & 19 & & & & & & & & \\
\hline $\begin{array}{l}\text { O.R. Truss } \\
\text { Joint (Back) }\end{array}$ & $\begin{array}{r}233 \\
22\end{array}$ & $\begin{array}{r}196 \\
14\end{array}$ & & $\begin{array}{r}37 \\
8\end{array}$ & 1230 & 1230 & 494 & .41 .0 & 368 & 913 & 812 & .364 \\
\hline$* 6$ & 550 & 557 & & -7 & & & & & & & & \\
\hline $\begin{array}{l}\text { Truss gage top } \\
\text { near front pl. }\end{array}$ & $\begin{array}{r}.95 \\
137\end{array}$ & $\begin{array}{l}-96 \\
141\end{array}$ & & $\begin{array}{r}1 \\
-4\end{array}$ & 236 & .33 & -236 & -19.1 & 102 & .55 & .215 & .63 \\
\hline$\# 7$ & .9 & .26 & & 17 & & & & & & & & \\
\hline $\begin{array}{l}\text { Truss gage bol } \\
\text { near front pl. }\end{array}$ & $\begin{array}{r}-24 \\
55\end{array}$ & $\begin{array}{r}-26 \\
56\end{array}$ & & $\begin{array}{r}2 \\
.1\end{array}$ & 485 & 485 & 0 & 4.5 & 242 & 482 & 3 & 38 \\
\hline \# 8 & 46 & 39 & & 7 & & & & & & & & \\
\hline $\begin{array}{l}\text { O.R. side flange } \\
\text { near front pl. }\end{array}$ & $\begin{array}{r}-11 \\
7\end{array}$ & $\begin{array}{r}1 \\
-13\end{array}$ & & $\begin{array}{r}-12 \\
20\end{array}$ & 809 & 607 & .202 & -41.9 & 405 & 246 & 159 & .402 \\
\hline$\# 9$ & 319 & 319 & & 0 & & & & & & & & \\
\hline $\begin{array}{c}\text { O.R. Truss } \\
\text { Joint (Front) }\end{array}$ & $\begin{array}{l}159 \\
174\end{array}$ & $\begin{array}{l}159 \\
149\end{array}$ & & $\begin{array}{r}0 \\
25\end{array}$ & 726 & 700 & -26 & 30.0 & 363 & 518 & 155 & 314 \\
\hline $\begin{array}{c}\# 10 \\
\text { O.R. Truss } \\
\text { Joint (Back) }\end{array}$ & $\begin{array}{l}303 \\
202 \\
216\end{array}$ & $\begin{array}{l}286 \\
188 \\
173\end{array}$ & & $\begin{array}{l}17 \\
14 \\
43\end{array}$ & 1398 & 1398 & 596 & 32.7 & 401 & 1164 & 830 & 364 \\
\hline
\end{tabular}


MFH Fourth Model Test, August 23, 1988

Stress Intensity Summary, Set 1/Set 2

\begin{tabular}{|c|c|c|c|c|c|c|c|c|c|c|c|}
\hline $\begin{array}{l}\text { Jack } \\
\text { Forco }\end{array}$ & (1b) & $\begin{array}{r}1800 \\
(\mathrm{Ib})\end{array}$ & $\begin{array}{r}3000 \\
(1 \mathrm{~b})\end{array}$ & $\begin{array}{r}4500 \\
(1 \mathrm{~b})\end{array}$ & $\begin{array}{r}5500 \\
\text { (lb) }\end{array}$ & $\begin{array}{r}6000 \\
(\mathrm{lb})\end{array}$ & $\begin{array}{r}5500 \\
\text { (Ib) }\end{array}$ & $\begin{array}{r}4500 \\
\text { (lb) }\end{array}$ & $\begin{array}{r}3000 \\
\text { (1b) }\end{array}$ & $\begin{array}{r}1800 \\
\text { (1b) }\end{array}$ & $\begin{array}{r}0 \\
\text { (1b) }\end{array}$ \\
\hline $\begin{array}{c}\# 1 \\
\text { Truss gage top } \\
\text { near front pl. } \\
\# 2\end{array}$ & $\begin{array}{l}952 \\
944\end{array}$ & $\begin{array}{l}3198 \\
2942\end{array}$ & $\begin{array}{l}5328 \\
5164\end{array}$ & $\begin{array}{l}7952 \\
7860\end{array}$ & $\begin{array}{l}9796 \\
9860\end{array}$ & $\begin{array}{l}10647 \\
10818\end{array}$ & $\begin{array}{l}9032 \\
9258\end{array}$ & $\begin{array}{l}7187 \\
7649\end{array}$ & $\begin{array}{l}4476 \\
4706\end{array}$ & $\begin{array}{l}2117 \\
2521\end{array}$ & $\begin{array}{l}944 \\
815\end{array}$ \\
\hline $\begin{array}{l}\text { Truss gage bot } \\
\text { near front pl. } \\
\qquad 3\end{array}$ & $\begin{array}{l}2299 \\
2751\end{array}$ & $\begin{array}{l}5250 \\
5631\end{array}$ & $\begin{array}{l}7222 \\
7579\end{array}$ & $\begin{array}{r}9681 \\
10007\end{array}$ & $\begin{array}{l}11678 \\
11825\end{array}$ & $\begin{array}{l}12363 \\
12676\end{array}$ & $\begin{array}{l}11182 \\
11312\end{array}$ & $\begin{array}{l}9522 \\
9910\end{array}$ & $\begin{array}{l}7057 \\
7259\end{array}$ & $\begin{array}{l}4935 \\
5341\end{array}$ & $\begin{array}{l}2751 \\
2803\end{array}$ \\
\hline $\begin{array}{l}\text { O.R. side flange } \\
\text { near front pl. } \\
\qquad 4\end{array}$ & $\begin{array}{l}2001 \\
2309\end{array}$ & $\begin{array}{l}2630 \\
2933\end{array}$ & $\begin{array}{l}3083 \\
3302\end{array}$ & $\begin{array}{l}3639 \\
3876\end{array}$ & $\begin{array}{l}4127 \\
4198\end{array}$ & $\begin{array}{l}4428 \\
4444\end{array}$ & $\begin{array}{l}4146 \\
4150\end{array}$ & $\begin{array}{l}3764 \\
3838\end{array}$ & $\begin{array}{l}3210 \\
3257\end{array}$ & $\begin{array}{l}2765 \\
2849\end{array}$ & $\begin{array}{l}2309 \\
2300\end{array}$ \\
\hline $\begin{array}{c}\text { O.R. Truss } \\
\text { Joint (Front) } \\
\\
\end{array}$ & $\begin{array}{l}3255 \\
2876\end{array}$ & $\begin{array}{l}2336 \\
3148\end{array}$ & $\begin{array}{l}4553 \\
5055\end{array}$ & $\begin{array}{l}7919 \\
8102\end{array}$ & $\begin{array}{l}9779 \\
9932\end{array}$ & $\begin{array}{l}10501 \\
10691\end{array}$ & $\begin{array}{l}9216 \\
9419\end{array}$ & $\begin{array}{l}7447 \\
7927\end{array}$ & $\begin{array}{l}4551 \\
4788\end{array}$ & $\begin{array}{l}2510 \\
2954\end{array}$ & $\begin{array}{l}2876 \\
2858\end{array}$ \\
\hline $\begin{array}{c}\text { O.R. Truss } \\
\text { Joint (Back) } \\
\# 6\end{array}$ & $\begin{array}{l}1785 \\
1810\end{array}$ & $\begin{array}{l}3944 \\
4043\end{array}$ & $\begin{array}{l}6730 \\
7107\end{array}$ & $\begin{array}{l}11437 \\
11981\end{array}$ & $\begin{array}{r}14852 \\
15212\end{array}$ & $\begin{array}{l}16366 \\
16704\end{array}$ & $\begin{array}{l}14125 \\
14680\end{array}$ & $\begin{array}{l}11006 \\
12071\end{array}$ & $\begin{array}{l}6273 \\
6837\end{array}$ & $\begin{array}{l}3128 \\
3793\end{array}$ & $\begin{array}{l}1810 \\
1890\end{array}$ \\
\hline $\begin{array}{c}\text { Truss gage top } \\
\text { near front pl. } \\
\\
7\end{array}$ & $\begin{array}{l}3079 \\
2948\end{array}$ & $\begin{array}{l}514 \\
264\end{array}$ & $\begin{array}{l}2026 \\
1977\end{array}$ & $\begin{array}{l}4684 \\
4494\end{array}$ & $\begin{array}{l}6446 \\
6315\end{array}$ & $\begin{array}{l}7314 \\
7215\end{array}$ & $\begin{array}{l}5909 \\
5820\end{array}$ & $\begin{array}{l}4164 \\
4383\end{array}$ & $\begin{array}{l}1587 \\
1606\end{array}$ & $\begin{array}{l}752 \\
448\end{array}$ & $\begin{array}{l}2948 \\
2922\end{array}$ \\
\hline $\begin{array}{c}\text { Truss gage bot } \\
\text { near tront pl. } \\
\\
8\end{array}$ & $\begin{array}{r}1007 \\
930\end{array}$ & $\begin{array}{l}1465 \\
1626\end{array}$ & $\begin{array}{l}2952 \\
3085\end{array}$ & $\begin{array}{l}5182 \\
5099\end{array}$ & $\begin{array}{l}6708 \\
6674\end{array}$ & $\begin{array}{l}7552 \\
7523\end{array}$ & $\begin{array}{l}6327 \\
6276\end{array}$ & $\begin{array}{l}4997 \\
5099\end{array}$ & $\begin{array}{l}2725 \\
2822\end{array}$ & $\begin{array}{l}1216 \\
1405\end{array}$ & $\begin{array}{l}930 \\
900\end{array}$ \\
\hline $\begin{array}{l}\text { O.R. side flange } \\
\text { near tront pl. } \\
\\
\quad 9\end{array}$ & $\begin{array}{l}1875 \\
2085\end{array}$ & $\begin{array}{l}2533 \\
2331\end{array}$ & $\begin{array}{l}3911 \\
3568\end{array}$ & $\begin{array}{l}5633 \\
5374\end{array}$ & $\begin{array}{l}6795 \\
6522\end{array}$ & $\begin{array}{l}7308 \\
7097\end{array}$ & $\begin{array}{l}6484 \\
6236\end{array}$ & $\begin{array}{l}5290 \\
5282\end{array}$ & $\begin{array}{l}3317 \\
3270\end{array}$ & $\begin{array}{l}2028 \\
2107\end{array}$ & $\begin{array}{l}2085 \\
2050\end{array}$ \\
\hline $\begin{array}{l}\text { O.R. Truss } \\
\text { Joint (Front) }\end{array}$ & $\begin{array}{l}4951 \\
4421\end{array}$ & $\begin{array}{l}1312 \\
2436\end{array}$ & $\begin{array}{l}3675 \\
4710\end{array}$ & $\begin{array}{l}6991 \\
7464\end{array}$ & $\begin{array}{l}9006 \\
9124\end{array}$ & $\begin{array}{r}9970 \\
10018\end{array}$ & $\begin{array}{l}8856 \\
8803\end{array}$ & $\begin{array}{l}7230 \\
7399\end{array}$ & $\begin{array}{l}4287 \\
4368\end{array}$ & $\begin{array}{l}2171 \\
2261\end{array}$ & $\begin{array}{l}4421 \\
4372\end{array}$ \\
\hline $\begin{array}{c}\text { \#10 } \\
\text { O.R. Truss } \\
\text { Joint (Back) }\end{array}$ & $\begin{array}{l}5046 \\
5078\end{array}$ & $\begin{array}{l}1618 \\
1577\end{array}$ & $\begin{array}{l}2608 \\
2182\end{array}$ & $\begin{array}{l}5790 \\
5562\end{array}$ & $\begin{array}{l}8209 \\
8001\end{array}$ & $\begin{array}{l}9353 \\
9277\end{array}$ & $\begin{array}{l}7502 \\
7390\end{array}$ & $\begin{array}{l}5133 \\
5468\end{array}$ & $\begin{array}{l}1772 \\
1838\end{array}$ & $\begin{array}{l}1997 \\
1739\end{array}$ & $\begin{array}{l}5078 \\
5029\end{array}$ \\
\hline
\end{tabular}




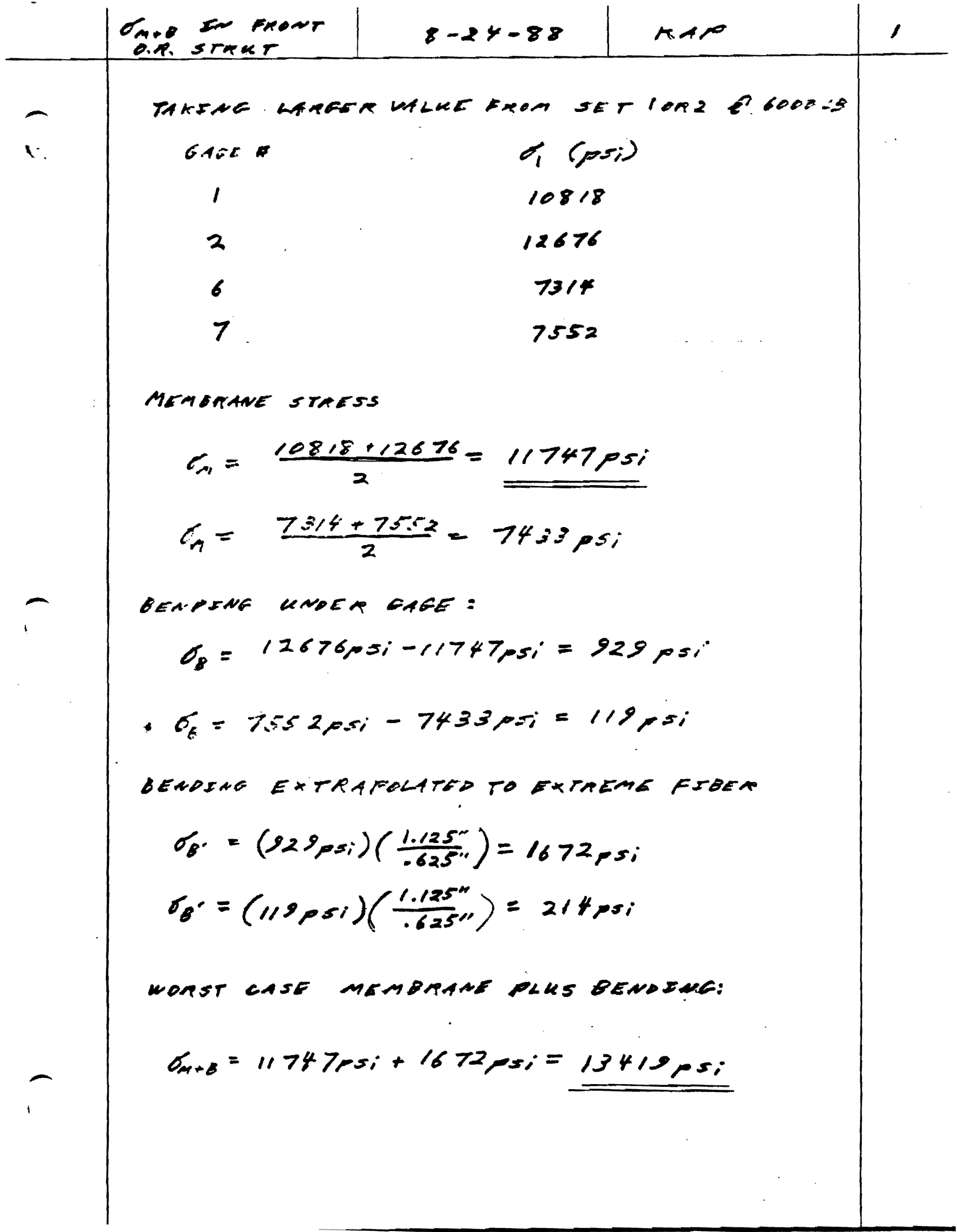




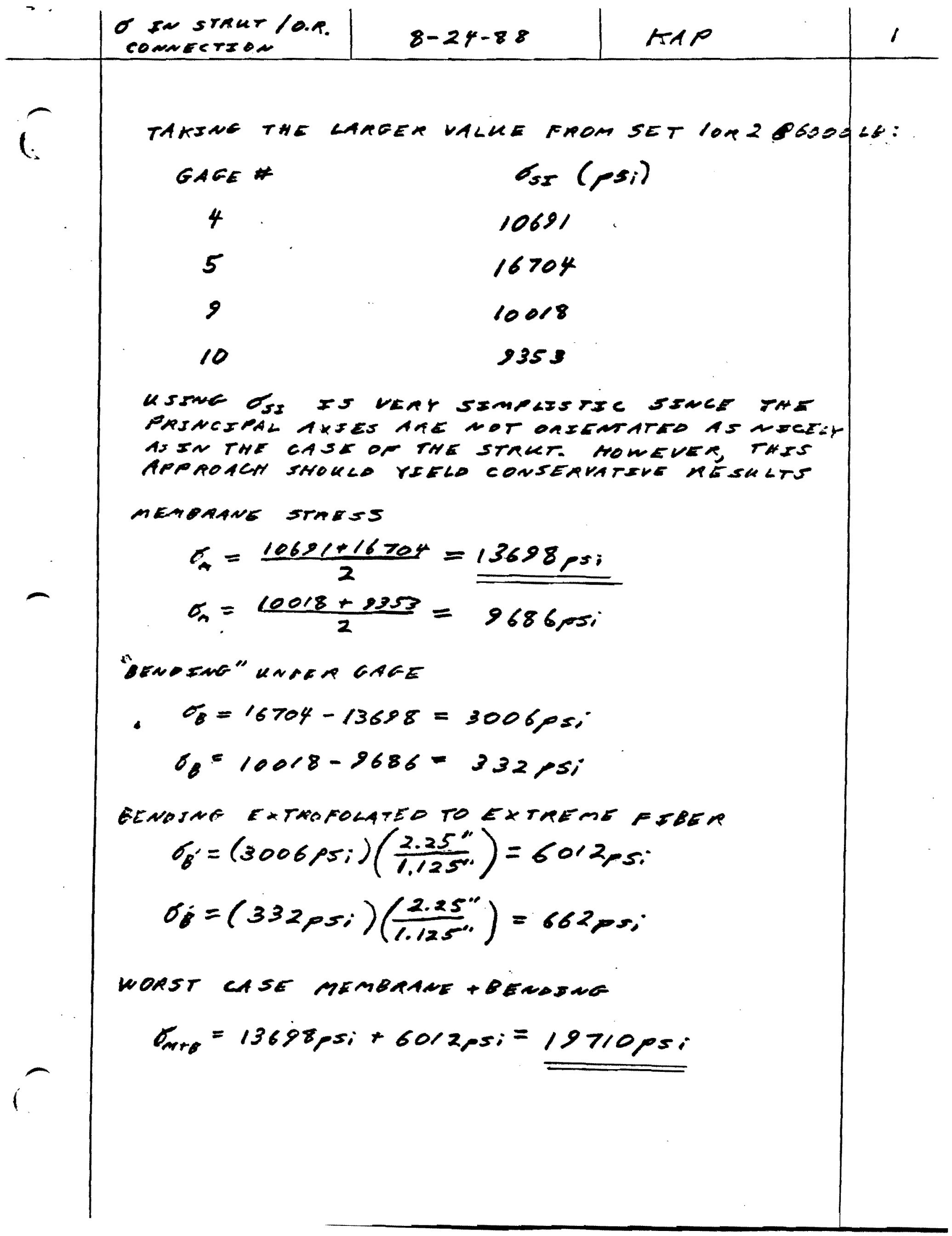




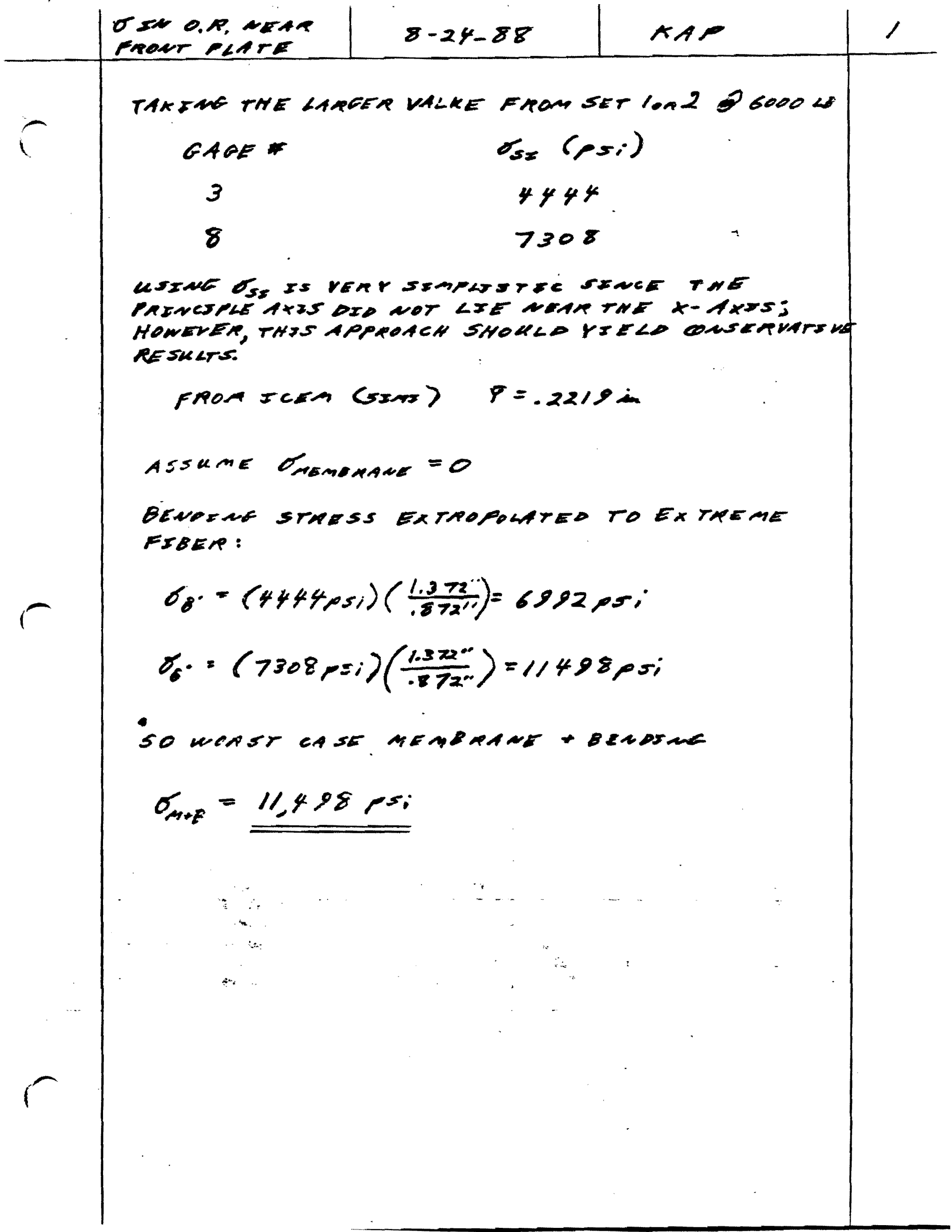

